Cintia Freire Garcia Vieira Braga' Lamartine Vieira Braga²
* Artigo recebido em abril de 2012.

Aprovado em agosto de 2012.

1 Mestranda em Direito Administrativo pela Universidade Católica Portuguesa; Especialista em Direito Tributário pelo IBET; Graduada em Direito pelo UniCeub. Procuradora da Fazenda Nacional.

2 Doutorando em Administração pela Universidade de Brasília, atualmente em estágio na University of Edinburgh Business School do Reino Unido; Especialista em Políticas Públicas e Gestão Governamental.

\section{O regime jurídico das concessões e permissões de uso de bens públicos no Brasil: aplicabilidade da lei de licitações*}

\section{The legal regime of concessions and permissions for use of public goods in Brazil: applicability of procurement law}

\section{Resumo}

O presente artigo tem como objetivo analisar a aplicabilidade da Lei $n^{\circ} 8.666 / 93$ (Lei de Licitações) aos procedimentos de outorga de concessões e permissões de uso de bens públicos por particulares, em especial dos bens pertencentes aos municípios. Para tanto, lançou-se mão de uma metodologia de pesquisa qualitativa, com análise bibliográfica, documental e da legislação pertinente ao tema. Inicialmente, traçou-se um panorama do patrimônio estatal brasileiro, com os respectivos regimes de propriedade a que se submete. Em seguida, fixaram-se o conceito e os atributos dos bens públicos no Direito Brasileiro, bem como o regime jurídico aplicável às outorgas de uso do patrimônio do Estado. A conclusão a que se chega é que a outorga do uso de bens públicos, embora não se submeta às regras de contratação pública contidas na Lei de Licitações, deve sempre ser efetivada no afã de concretizar os princípios constitucionais que pautam a atividade administrativa.

Palavras-chave: Concessões. Permissões. Lei de Licitações. Bens públicos. Brasil.

\begin{abstract}
This article aims to analyze the applicability of Law n. 8.666/93 (Brazilian Procurement Law) to procedures for granting concessions and permissions for use of public goods by private individuals, especially from property belonging to the municipalities. To this end, it employed a qualitative research methodology, with literature review, document and pertinent legislation. Initially, there is an overview of the Brazilian state-owned assets, with the respective property regimes to which they submit. Then there are the concept and attributes of public goods in Brazilian Law and the legal regime applicable to grants of use of state property. The conclusion reached is that the granting of the use of public goods, although not subject to public procurement rules contained in the Brazilian Procurement Law, should always be carried out in order to implement the constitutional principles that guide the administrative activity.
\end{abstract}

Keywords: Concessions. Permissions. Procurement law. Public goods. Brazil. 


\section{Introdução}

Temos direito a reivindicar a igualdade sempre que a diferença nos inferioriza e temos direito de reivindicar a diferença sempre que a igualdade nos descaracteriza. ${ }^{3}$

O momento atualmente vivenciado pelo Brasil, pautado no crescimento econômico, aliado ao desenvolvimento social engendrado por forte intervenção estatal, por meio da implementação de políticas públicas de cunho redistributivo, tem repercutido na forma como se encara a propriedade do Estado.

Com efeito, na esteira de uma vaga nacionalista, surgida no bojo do Governo Lula da Silva (2003-2010), que sucede um período marcado pelo liberalismo do Governo Fernando Henrique Cardoso (1995-2002), passa-se de um contexto caracterizado pela gestão dos bens por demanda para uma postura de implementação de políticas de dinamização da propriedade pública, por meio do prestígio à sua "função socioambiental, em harmonia com a função arrecadadora, em apoio aos programas estratégicos para a Nação". Mais do que a preocupação em rentabilizar o patrimônio do Estado, o que se pretende é "priorizar a destinação de imóveis da União para políticas de inclusão social, preservação ambiental e apoio à provisão habitacional para a população de baixa renda." 5

Essa perspectiva nasce da superação do conceito de propriedade pública como "patrimônio da Administração Pública”, para situar os bens do domínio público em prestígio à sua vinculação à função social, como "patrimônio de todos" no âmbito do planejamento territorial participativo, que traduz o esforço de democratização do patrimônio, com vistas à redução da segregação territorial e do déficit habitacional brasileiro.

Historicamente, identifica-se no Brasil a preocupação do legislador voltada fundamentalmente para o escopo de discriminar as terras públicas das terras parti-

3 SANTOS, Boaventura de Souza. A gramática do tempo: para uma nova cultura política. São Paulo: Cortez, 2006. p. 44.

4 BRASIL. Ministério do Planejamento. Secretaria de Patrimônio da União. Disponível em: <http://patrimoniodetodos.gov. br/politica-nacional-de-gestao-do-patrimonio-da-uniao-pngpu>. Acesso em: 20 mar. 2012.

5 BRASIL. Ministério do Planejamento. Secretaria de Patrimônio da União. Política Nacional de Gestão do Patrimônio da União (PNGPU): princípios, diretrizes e desafios. Disponível em: <http://patrimoniodetodos.gov.br/politica-nacional-de-gestao-do-patrimonio-da-uniao-pngpu>. Acesso em: 20 mar. 2012. culares, evoluindo-se no sentido da diminuição do patrimônio público e a consequente ampliação do patrimônio particular.

A par disso, verifica-se, nesse iter evolutivo, o favorecimento da utilização de bens públicos por particulares, por variadas formas e com diversos objetivos, por vezes traduzindo o viés ideológico da chefia da Administração Pública de determinado momento histórico.

Nesse contexto, os instrumentos utilizados na dinamização da propriedade pública sobressaem como importante ferramenta na implementação desses objetivos, revelando a pertinência de precisar-lhes o conceito e o respectivo regime jurídico a que se devem submeter. Para tanto, faz-se mister despender um esforço interpretativo no sentido de desvendar questões que se colocam acerca do regime legal aplicável às concessões e permissões de uso de bem público, especialmente quanto à aplicabilidade das regras de concorrência para a formação dos respectivos contratos.

O objetivo do presente trabalho é analisar a aplicabilidade da Lei no 8.666/93 (Lei de Licitações) aos procedimentos de outorga de concessões e permissões de uso de bens públicos por particulares, em especial dos bens pertencentes aos municípios. Para tanto, traçou-se um panorama do patrimônio estatal brasileiro, com os respectivos regimes de propriedade a que se submete, fixaram-se o conceito e os atributos dos bens públicos no Direito Brasileiro, bem como o regime jurídico aplicável às outorgas de uso do patrimônio do Estado.

\section{0 patrimônio estatal: formas de propriedade do Estado}

A fixação do conceito de propriedade do Estado passa pela superação de duas questões preliminares: a caracterização da relação travada entre Estado e patrimônio como propriedade, superando a ideia de que o Estado não poderia deter como seu determinado bem, uma vez que apenas exerce funções em nome da coletividade; e o reconhecimento dessa mesma propriedade, porém despida do seu caráter absoluto, porquanto ao Estado não cabe usar, fruir ou dispor livremente da coisa.

A reflexão em torno dessas questões descortina a dificuldade enfrentada no âmbito do Direito Administrativo pertinente à equiparação do Estado às demais 
pessoas, físicas ou jurídicas, no que tange à natureza dos direitos de que é titular.

Nesse particular, convém não olvidar a crescente relativização que vem sofrendo os atributos de usar, fruir e dispor da coisa, em face da sujeição geral dos bens ao cumprimento de sua função social. ${ }^{6}$ Assim, cada vez mais, a utilidade ou vocação do bem em face das necessidades coletivas predica um regime derrogatório da liberdade absoluta sobre os bens, mesmo que privados. ${ }^{7}$

Relevante notar que o patrimônio público não é composto de bens de uma única natureza. Com efeito, convive-se hoje com a dicotomia domínio público e domínio privado da Administração. E é possível identificar a distinção entre o domínio público e privado do Estado pelo regime jurídico que lhes são aplicáveis respectivamente, e pela afetação destes "ao uso direto ou indireto da coletividade".

O Quadro 1 ilustra as formas de propriedade e os respectivos modelos de Administração Pública adotados no Brasil:

Quadro 1: Formas de Propriedade e de Administração Pública no Brasil ${ }^{9}$

\begin{tabular}{|c|c|c|c|c|c|}
\hline & Estatal & $\begin{array}{l}\text { Pública } \\
\text { Não Estatal }\end{array}$ & Privada & Burocrática & Gerencial \\
\hline $\begin{array}{l}\text { NÚCLEO ESTRATÉGICO } \\
\text { Legislativo, Judiciário, } \\
\text { Presidência, Cúpula dos } \\
\text { Ministérios, Ministério } \\
\text { Público }\end{array}$ & & & & & \\
\hline $\begin{array}{l}\text { ATIVIDADES EXCLUSIVAS } \\
\text { Regulamentação } \\
\text { Fiscalização, Fomento, } \\
\text { Segurança Pública, } \\
\text { Seguridade Social Básica }\end{array}$ & & & & & \\
\hline \begin{tabular}{|l|} 
SERVICCOS NÃO- \\
EXCLUISVOS \\
Universidades, Hospitais, \\
Centros de Pesquisa, \\
Museus
\end{tabular} & Publicização & & & & \\
\hline $\begin{array}{l}\text { PRODUÇÃO PARA O } \\
\text { MERCADO } \\
\text { Empresas Fstatais }\end{array}$ & & Privatização & & & \\
\hline
\end{tabular}

${ }_{6}$ BRASIL. Lei $\mathrm{n}^{\circ} 10.257 / 2001$. Art. 39. "A propriedade urbana cumpre sua função social quando atende às exigências fundamentais de ordenação da cidade expressas no plano diretor, assegurando o atendimento das necessidades dos cidadãos quanto à qualidade de vida, à justiça social e ao desenvolvimento das atividades econômicas, respeitadas as diretrizes previstas no art. $2^{\circ}$ desta Lei."

7 DI PIETRO, Maria Sylvia Zanella. Servidão administrativa. São Paulo: Revista dos Tribunais, 1978.

8 CRETELLA JÚNIOR, José. Tratado do domínio público. Rio de Janeiro: Forense, 1984

9 BRASIL. Presidência da República. Câmara da Reforma do Estado. Plano Diretor da Reforma do Aparelho do Estado. Brasília, 1995.
Os diversos setores do Estado demandam diferentes formas de regime dos bens a que estão afetos. Assim, ao legislador incumbe a tarefa de delimitar os diversos núcleos da função estatal, relacionando-os aos respectivos regimes de propriedade.

Nesse contexto, o núcleo estratégico do Estado demanda o regime necessariamente estatal. Deveras, quando estão em atividades exclusivas de Estado, em que o poder soberano do Estado é exercido, o regime de bens só pode ser o público. Em outro giro, em setores não exclusivos, ou competitivos do Estado, notadamente os setores econômicos nos quais o Estado desempenha uma função que não é essencialmente própria, ou juridicamente privativa, o regime ideal da propriedade é o público não estatal.

Nesse setor, voltado à produção de bens e serviços para o mercado, a eficiência é também o princípio administrativo básico e a administração gerencial a mais indicada. Em termos de propriedade, a regra é a da propriedade privada. A propriedade estatal, nesse caso, só encontra justificativa ante a ausência de capitais privados disponíveis - o que não é mais a realidade brasileira - ou então em caso de monopólio natural que, ainda assim, pode encontrar na gestão privada uma forma mais adequada de gerenciamento, desde que acompanhada por um eficiente sistema de regulação. Em todo caso, faz-se necessário empreender esforços para dinamizar a propriedade estatal, direcionando-lhe para a consecução de fins de interesse público (que representa um autêntico poder-dever do gestor público), não somente quanto ao aspecto de rentabilização dos bens públicos, por si só relevante, mas igualmente no prestígio à função social da propriedade, vetor constitucional de aplicabilidade ampla, tanto a bens particulares quanto públicos. ${ }^{10}$ Essa imposição, aliás, faz-se premente em face do panorama habitacional brasileiro.

${ }^{10}$ BRASIL. Constituição (1988). Constituição da Republica Federativa do Brasil. Brasília: Congresso Nacional, 1988. "art. $5^{\circ}$. Todos são iguais perante a lei, sem distinção de qualquer natureza, garantindo-se aos brasileiros e aos estrangeiros residentes no País a inviolabilidade do direito à vida, à liberdade, à igualdade, à segurança e à propriedade, nos termos seguintes: [...] XXIII - a propriedade atenderá a sua função social". 
Com efeito, verifica-se no Brasil uma crise urbana ${ }^{11}$ de grande proporção: dos 44 milhões de domicílios, mais de 12 milhões estão em situação de irregularidade fundiária. $\mathrm{O}$ déficit habitacional brasileiro, que supera 7 milhões de unidades, ${ }^{12}$ revela o tamanho do desafio hoje enfrentado pelas cidades brasileiras, cuja maioria é composta de aglomerados urbanos informais e precários, causa fundamental de constante tensão social. ${ }^{13}$ Significativa parcela desses assentamentos informais ocupa área pública, circunstância que revela uma política de urbanização bem orientada, com a correta destinação do uso do patrimônio público, tem potencial de gerar significativa repercussão na busca pela solução desse grave problema social. ${ }^{14}$ Esse esforço constitui hoje dever constitucionalmente imposto ao gestor público, porquanto,

[...] a institucionalidade democrática brasileira, fundada a partir da Constituição Federal de 1988, reconhece o uso dos imóveis públicos para fins de moradia da população de menor renda. Desta forma, o regime jurídico da propriedade pública é profundamente alterado, com o reconhecimento do direito subjetivo à moradia dos ocupantes de áreas públicas. Aproxima-se o interesse público do interesse social, unificando o interesse público e privado ao efetivar o direito fundamental à moradia em áreas públicas. É a propriedade pública afetada à redução das desigualdades sociais e regionais do país ".15

${ }^{11}$ Atualmente, cerca de $80 \%$ da população do país mora em área urbana. BRASIL. Ministério das Cidades. Política Nacional de Habitação. 2004. Disponível em <http://www.cidades.gov. br>. Acesso em: 20 mar. 2012.

12 BRASIL. Ministério das Cidades. Política Nacional de Habitação. 2004. Disponível em <http://www.cidades.gov.br>. Acesso em: 20 mar. 2012.

13 "Mais de $97 \%$ das cidades com mais de 500 mil habitantes têm favelas, $80 \%$ das cidades entre 100 e 500 mil habitantes, em $45 \%$ das cidades entre 20 e 100 mil habitantes e, ainda, em $36 \%$ das cidades pequenas, com menos de 20 mil habitantes, têm assentamentos irregulares e $20 \%$ possuem favelas, conforme censo IBGE (2000)". ALFOSIN, Betânia; FERNANDES, Edésio. Princípios, bases e desafios de uma política nacional de apoio à regularização fundiária sustentável. In: (Org.). Direito à moradia e segurança da posse no Estatuto da Cidade. Porto Alegre: Fórum, 2004.

${ }^{14}$ Sobressai evidente que a provisão de moradia, por si só, não garante a inclusão social. Fatores como a localização, o acesso aos serviços, aos equipamentos, à segurança, ao mercado de trabalho, são fundamentais para assegurar o direito à cidade sustentável.

${ }^{15}$ CARDOSO, Patrícia de Menezes. Democratização do acesso à propriedade pública no Brasil: função social e regularização fundiária. Pontifícia Universidade Católica de São Paulo, 2010. Disponível em < http://patrimoniodetodos.gov.br/olhares-sobre-o-patrimonio-de-todos >. Acesso em: 20 mar. 2012.
Nesse cenário, impende salientar que, independentemente da categoria jurídica dos bens públicos envolvidos, releva identificar as utilidades que deles emergem e que carreiam benefícios à sociedade, especialmente quanto ao seu potencial de repercussão na população de baixa renda.

Para essa parcela significativa da sociedade, a utilização dos imóveis públicos (sobretudo quando atribuída de forma gratuita) ${ }^{16}$ constitui ferramenta apta a concretizar as garantias e direitos fundamentais constitucionalmente assegurados a todos os cidadãos (direito à moradia, à cidade, à identidade e à dignidade). ${ }^{17}$ Assim, a utilização dos bens públicos pela coletividade, sob a perspectiva socioinclusiva, sobressai como forma de efetivar interesse geral, objetivo precípuo de todo atuar administrativo, ao tempo em que satisfaz o mandamento constitucional pertinente aos direitos fundamentais, devendo, por isso mesmo, ser reconhecida e fomentada no âmbito das políticas públicas.

O patrimônio público constitui estoque fundiário estratégico. Sua utilização deve, por força de comando constitucional expresso, ser orientada para a redução das desigualdades sociais e territoriais e para a promoção da justiça social, ${ }^{18}$ garantindo os direitos sociais, ${ }^{19}$ dentre os
${ }^{16}$ BRASIL. Código Civil Brasileiro (Lei n. 10.406, de 10 de janeiro de 2002). Art. 103. O uso comum dos bens públicos pode ser gratuito ou retribuído, conforme for estabelecido legalmente pela entidade a cuja administração pertencerem. Disponível em < http://www.planalto.gov.br/ccivil_03/leis/2002/ 110406.htm >. Acesso em: 20 mar. 2012.

${ }^{17}$ Pode-se destacar, dos direitos fundamentais afetos à vida urbana, no âmbito dos direitos individuais, o direito à vida, à dignidade, à liberdade, à privacidade, à propriedade (art. $5^{\circ}$, $\mathrm{CF} / 88$ ). Dentre os direitos sociais, o direito à moradia, previsto no art. $6^{\circ}$, da Lei Maior, o direito à regularização fundiária (art. 2º XIX, Lei n. 10.257/2001) e o direito ao planejamento urbano (art. 182, CF/88). Dentre os direitos difusos, destacam-se o direito ao meio ambiente sadio e equilibrado (art. $225, \mathrm{CF} / 88$ ) e o direitos à cidade e à gestão democrática da cidade (art. 2, I e II, da Lei n. 10.257/2001).

${ }^{18}$ Art. 3º, III e IV. BRASIL. Constituição (1988). Constituição da República Federativa do Brasil. Brasília: Congresso Nacional, 1988.

${ }^{19}$ Art. 6. BRASIL. Constituição (1988). Constituição da República Federativa do Brasil: Brasília: Congresso Nacional, 1988. 
quais se insere o direito à moradia digna, ${ }^{20}$ zelando pela proteção ao meio ambiente e ao patrimônio históricocultural, em apoio ao desenvolvimento regional e nacional, inclusive no pertinente à ampliação da oferta de serviços públicos. É sob esse paradigma que deve ser repensada a propriedade pública: como instrumento capaz de gerar utilidades públicas relevantes à sociedade, contribuindo para a redução da acentuada disparidade socioeconômica da população brasileira, o que certamente contribuirá de maneira decisiva para o desenvolvimento social do país. Sua gestão deve orientar-se pelo esforço de inclusão territorial de forma ambientalmente sustentável, a fim de consolidar o direito à cidade organizada, limpa e segura, corolário do direito à dignidade humana.

\section{0 domínio estatal no direito brasileiro}

Repensar a propriedade pública remete ao resgate da memória e da identidade territorial brasileira, sem o qual não é possível analisar o potencial de mudança requerida, com urgência, pela sociedade brasileira.

Historicamente, o regime dos bens do Estado Brasileiro revela peculiaridades decorrentes do processo de ocupação do território nacional. Deveras, nota-se que, diferentemente do que ocorreu nos diversos países da Europa, em que a propriedade trilhou um iter evolutivo de apropriação privada contraposta ao domínio do soberano, no caso brasileiro, a constituição do domínio privado se inicia a partir da transferência da propriedade pela Coroa para mãos particulares.

Após a chegada portuguesa, o território compreendido até a linha divisória do Tratado de Tordesilhas passou a integrar o patrimônio da Coroa do Reino de Portugal. O processo de transferência de tais bens para a propriedade privada inicia pelas Capitanias Hereditárias e, posteriormente, por via da concessão de sesmarias. A definição do encargo de cultivo das Sesmarias, concedidas administrativamente, sujeitas à obrigação de registro,

${ }^{20} \mathrm{O}$ direito à moradia ostenta característica “[...] não só de direito social, mas, sob este prisma, também de direito personalíssimo, fundamental e humano, ante seu liame existente com a necessidade básica de sobrevivência do indivíduo". IGLESIAS, Sérgio Nunes de Souza. Direito à moradia e de habitação: análise comparativa de suas implicações teóricas e práticas com os direitos da personalidade. São Paulo: Revista dos Tribunais, 2004. de mediação, de pagamento de foro e de possibilidade de confisco em face do descumprimento das cláusulas contratuais, conformaram o regime jurídico da propriedade pública no Brasil entre 1500 a 1822. Paralelamente, verificou-se a ocupação privada por meio de mera posse, ${ }^{21}$ dada a dificuldade de gestão territorial, marcada pela distância geográfica da administração da Coroa e as dimensões continentais do território colonial.

A forma como se desenvolveu a ocupação do território brasileiro, originalmente embasada na concessão de títulos de Sesmaria, e seguida da ocupação pelo regime de posses, ${ }^{22}$ originou um mecanismo de apropriação patrimonial de grandes extensões de terras, antes públicas, posto pertencentes originariamente à Coroa Portuguesa, e que, depois, serviram de baliza para a concepção do patrimônio da Nação, então emancipada do colonizador, uma vez que o conjunto de bens do Estado passou a existir como um remanescente das terras não ocupadas pelos particulares, designadas de terras devolutas. Assim, às avessas, o domínio do Estado brasileiro se deu a partir da abertura ao apossamento privado, ao fim do que se seguiu a constituição do patrimônio da nação com os bens que remanesceram desse processo de ocupação. Diversamente da dinâmica desenvolvida na Europa, a demarcação do patrimônio público não foi uma preocupação concomitante à afirmação do Estado constitucional no Brasil. ${ }^{23}$ Proclamada a independência, a Constituição Imperial de 1824 garantiu o direito de propriedade em toda sua plenitude. ${ }^{24}$ A gestão dos bens integrantes do patrimônio público no Brasil, ao longo dos anos, deu-se, em geral, de maneira desordenada, utilizando-se da forma cartorá-

${ }^{21}$ OTÁVIO, Rodrigo. Do domínio da União e dos Estados segundo a Constituição Federal. 2. ed. São Paulo: Saraiva, 1924.

${ }^{22}$ Com a exaustão dos bens a distribuir, a terra passa a ser adquirida pela herança, doação, compra e, sobretudo, pela ocupação - a posse, transmissível por sucessão e alienável pela compra e venda. FAORO, Raymundo. Os donos do poder: formação do patronato político brasileiro. 3. ed. São Paulo: Globo, 2001.

${ }^{23}$ MARQUES NETO, Floriano de Azevedo. Bens públicos: função social e exploração econômica: o regime jurídico das utilidades públicas. Belo Horizonte: Fórum, 2009.

${ }^{24}$ BRASIL. Constituição (1824). Constituição Política do Império do Brasil. Rio de Janeiro: Imprensa Nacional, 1824. "XXII. É garantido o Direito de Propriedade em toda a sua plenitude. Se o bem público legalmente verificado exigir o uso e emprego da Propriedade do Cidadão, será elle préviamente indemnisado do valor della. A Lei marcará os casos, em que terá logar esta única excepção, e dará as regras para se determinar a indemnisação." (SIC). 
ria e orientada pela função arrecadadora, em detrimento da gestão urbano-ambiental do território, voltada à promoção do desenvolvimento nacional. Atualmente, essa postura tem sido alvo de severas críticas e objeto de importantes alterações legislativas e políticas. No contexto brasileiro atual, inaugurado pelo prestígio constitucional outorgado à função social da propriedade, ${ }^{25} \mathrm{e}$ acentuado após o início do Governo Lula, ao binômio proteção-rentabilização, pretende-se atribuir uma característica triangular: acresce-se à preocupação do legislador e do gestor público a necessidade de se imprimir ao regime jurídico da propriedade pública (coletiva) o viés social, nota característica de várias políticas públicas engendradas no panorama brasileiro e objeto de relevantes alterações legislativas recentes. ${ }^{26}$

O princípio da função social da propriedade, cuja origem remonta à Constituição de Weimar, de 1919, traduz reação contra a concepção meramente individualista da propriedade privada e exprime concepções ideológicas que pretendem extrair dela a função de instrumento para a prossecução do bem comum. ${ }^{27}$ Esse princípio cria para o particular, proprietário, um ônus: o dever de utilização do seu patrimônio, de forma socialmente adequada. ${ }^{28}$

Em se tratando de bens que integram o patrimônio público, pode-se extrair seu aspecto social pelo tão-só fato de tratar-se de bens de domínio de pessoa jurídica de direito público, vocacionados, por isso mesmo, à satisfação de necessidades de caráter geral. Mas sua função

${ }^{25}$ BRASIL. Constituição (1988). Constituição da Republica Federativa do Brasil. Brasília: Senado Federal, 1988. Prevê o princípio da função social da propriedade no capítulo relativo aos direitos individuais (art. $5^{\circ}$, XXIII), bem como, naquele destinado à ordem econômica (art. 170, III), associando umbilicalmente esses dois conceitos - propriedade e função social.

${ }^{26}$ Em 31 de maio de 2007 foi promulgada a Lei $\mathrm{n}^{\circ} 11.481$, que disciplina a concessão especial para fins de moradia e determina a aplicação do referido instituto aos bens do domínio da União, inclusive terrenos de marinha e acrescidos..

${ }^{27}$ DI PIETRO, Maria Sylvia Zanella. Função social da propriedade pública. Revista Eletrônica de Direito do Estado, Salvador, n. 6, p. 1-13, trimestral, 2006.

28 "Consiste a função social da propriedade no dever de cumprir um destino economicamente útil, produtivo, de maneira a satisfazer às necessidades sociais preenchíveis pela espécie do bem (ou pelo menos não poderá ser utilizada de modo a contraditar esses interesses), de modo que, o bem deve cumprir a exata funcionalidade que dele se espera em proveito da coletividade”. ABE, Nilma de Castro. Notas sobre a inaplicabilidade da função social à propriedade pública. Revista Brasileira de Direito Constitucional, n. 11, p. 135-154, jan./jun. 2008. social não se esgota aí. Deveras, o domínio público da propriedade não se mostra suficiente à concretização do princípio da função social da propriedade, dependendo ela da utilização efetiva dos imóveis públicos a serviço do interesse coletivo.

No Brasil, a função social da propriedade privada recebeu status constitucional com o advento da Carta de 1967. Sua aplicabilidade, relativamente ao domínio público, pode ser inferida por meio da leitura de alguns dispositivos constitucionais que tratam da política urbana. ${ }^{29}$ Releva consignar que, ao falar em função, fala-se em dever, o dever imposto ao Poder Público de disciplinar a utilização dos bens, fiscalizar essa utilização, reprimir condutas que a desrespeitem, tudo de modo a garantir que ela se concretize para fins de interesse geral, extraindo-se dela o máximo benefício à coletividade. Sob essa perspectiva, sobressai nítido que ao Poder Público impõe-se disciplinar o uso dos bens públicos, conciliando suas múltiplas formas de utilização, sempre orientado pela adequação do uso com o fim principal a que eles estão afetos, e pela busca da satisfação do interesse público.

Atendendo aos princípios consagrados no Texto Constitucional e às exigências que emergem da configuração da sociedade brasileira, a forma mais adequada de empregar os bens públicos deve orientar-se necessariamente ao atendimento dos interesses de caráter geral, especialmente na promoção de uma sociedade mais igualitária, de molde a permitir a concretização dos direitos individuais e sociais a todos. A gestão do patrimônio público deve ser respaldada em processos democráticos e transparentes de tomada de decisões no âmbito da formulação, execução e monitoramento das respectivas políticas públicas, de forma a imprimir-lhe legitimidade e eficiência.

\section{Bens públicos: conceito e atributos}

Os bens públicos pressupõem a existência de uma estrutura Estado-Administração, pois importam em tra-

\footnotetext{
${ }^{29}$ Sua definição constitucional é informada por meio de diretrizes a serem observadas pelo Poder Público, como a que se extrai do art. 182, que traça como objetivo da política de desenvolvimento urbano "[...] o pleno desenvolvimento das funções sociais da cidade e garante o bem estar de seus habitantes". BRASIL. Constituição (1988). Constituição da República Federativa do Brasil. Brasília: Congresso Nacional, 1988.
} 
tar necessariamente dos efeitos da personalidade jurídica do Estado. De fato, somente a partir do momento em que o Estado passa a ser sujeito de direitos e obrigações é que se mostra possível atribuir-lhe domínio sobre coisas dotadas de valor econômico. ${ }^{30}$ Assim, a partir da afirmação de que o Estado é detentor de personalidade jurídica própria, extrai-se que é dotado de capacidade para adquirir direitos e contrair obrigações. E uma das características da personalidade é a possibilidade de possuir patrimônio próprio. ${ }^{31}$

A construção da personalidade jurídica do Estado e a delimitação dos seus direitos de propriedade contribuíram de maneira determinante à formação e ao desenvolvimento da sociedade moderna. Nota característica da noção de bem público prende-se ao seu fundamento finalístico, uma vez que, somente se justifica uma relação dominial a partir da existência de um interesse geral, público, subjacente, e que reflete necessariamente nos parâmetros a serem observados em sua respectiva gestão. $\mathrm{O}$ conceito de patrimônio público, a partir dessa premissa, pode ser delineado como a existência plena de relações de propriedade titularizadas pelos entes públicos, relações estas contendidas pelas condicionantes de sua aplicação aos interesses gerais. ${ }^{32}$

Note-se que a separação moderna entre público e privado tem sua origem, não na necessidade de afirmação do espaço do poder político, mas ao contrário, decorre da necessidade imposta pela ascensão da ordem capitalista de se afirmar, a fim de preservar e garantir a esfera privada. Com isso, torna-se possível construir a sociedade calcada na liberdade individual em sede de mercado, a par de se definir, a partir da imposição de limites a unicidade do poder público. E é precisamente nesse ponto que ao conceito dominial, a partir do qual a noção de bem público atrela-se ao direito de propriedade da pessoa jurídica - Estado, será agregado o aspecto funcional, ou finalístico: o poder da autoridade pública fica cingida e condicionada ao atingimento de uma finalidade de interesse geral que a legitima. Nesse particular, releva refletir

${ }^{30}$ MARQUES NETO, Floriano de Azevedo. Bens públicos: função social e exploração econômica: o regime jurídico das utilidades públicas. Belo Horizonte: Fórum, 2009.

${ }^{31}$ ARAÚJO, Edmir Netto. Curso de direito administrativo. São Paulo: Saraiva, 2005.

32 CRETELLA JÚNIOR, José. Dos bens públicos na Constituição de 1988. Revista dos Tribunais, São Paulo, v. 79, n. 653, p. 16-48, mar. 1990. sobre a dicotomia existente na seara dos bens públicos, precisamente no que se refere ao patrimônio estatal, cuja titularidade remete à pessoa jurídica de direito público Estado, titular dos direitos de propriedade inerentes aos bens e ao patrimônio público-comum, atinente ao conjunto de bens cuja titularidade, por sua natureza, não é suscetível de apropriação, remanescendo na propriedade do Estado em decorrência de sua soberania.

O conceito de domínio público ${ }^{33}$ é pautado a partir de duas concepções que revelam diferentes critérios adotados para a delimitação dos bens públicos: a relação de titularidade e a relação funcional. É a partir da visão funcional da propriedade pública que é construída a doutrina que concebe duas formas de domínio por parte do Estado: os bens do domínio público e os bens do domínio privado da Administração. ${ }^{34}$ Embora acolhido o critério finalístico pela doutrina administrativista brasileira, ${ }^{35}$ no direito positivo, a definição do regime jurídico dos bens públicos, de origem civilista, prende-se à sua titularidade. ${ }^{36}$ Assim, são bens públicos "[...] os bens do domínio nacional pertencentes às pessoas jurídicas de direito público interno, todos os outros são particulares, seja qual

${ }^{33}$ Impende ressalvar o caráter polissêmico da expressão: "A expressão domínio público é equívoca, no sentido de que admite vários significados: em sentido muito amplo, é utilizada para designar o conjunto de bens pertencentes às pessoas jurídicas de direito público interno [...]; em sentido menos amplo, utilizado na referida classificação do direito francês, designa os bens afetados a um fim público [...]; em sentido restrito, fala-se em bens do domínio público para designar apenas os destinados ao uso comum do povo, correspondendo ao demanio do direito italiano". DI PIETRO, Maria Sylvia Zanella. Direito administrativo. 24. ed. São Paulo: Atlas, 2011.

${ }^{34}$ DI PIETRO, Maria Sylvia Zanella. Direito administrativo. 24. ed. São Paulo: Atlas, 2011.

35 "A grande maioria dos administrativistas - embora com variações e combinando-se com o requisito da titularidade abraça a concepção funcionalista, colocando relevo na definição de bens públicos relacionada à função de interesse geral que eles cumprem". MARQUES NETO. Floriano de Azevedo. Bens públicos: função social e exploração econômica: o regime jurídico das utilidades públicas. Belo Horizonte: Fórum, 2009.

${ }^{36}$ Note que há uma diferença conceitual entre o Direito Brasileiro e o Direito Europeu Português relativamente ao domínio público. Enquanto no Direito Português os bens de propriedade privada do Estado são submetidos ao regime civil (privado), remanescendo sob o regime público apenas os bens de propriedade pública, no Direito Brasileiro todos os bens de propriedade do Estado são submetidos a um regime próprio, administrativo, ainda que com nuances diversas, atendendo às diferentes finalidades a que estão afetos (como no caso dos bens dominicais, não afetos a finalidade pública específica e que podem ser alienados nos termos da lei). 
for a pessoa a que pertencerem" ${ }^{37}$ Com efeito, desde o Código Civil de 1916, o Brasil adota a classificação dos bens públicos em três espécies: os bens de uso comum do povo (ou do domínio público), ${ }^{38}$ bens de uso especial (ou do patrimônio administrativo) ${ }^{39}$ e bens dominicais (também denominados bens dominiais). ${ }^{40} 41$

São características de que se revestem os bens públicos a inalienabilidade (ou alienabilidade nos termos da lei, já que os bens dominicais podem ser alienados, se a lei assim o dispuser), ${ }^{42}$ isto é, a impossibilidade, sal-

${ }^{37}$ (Lei n. 10.406, de 10 de janeiro de 2002), art. 98. BRASIL. Código Civil Brasileiro. Disponível em < http://www.planalto. gov.br/ccivil_03/leis/2002/110406.htm >. Acesso em: 20 mar. 2012.

${ }^{38} \mathrm{O}$ uso comum é aquele posto ao dispor dos administrados, independentemente de qualquer titulação específica ou do cumprimento de qualquer condição prévia. Três elementos o caracterizam: generalidade, impessoalidade, e incondicionalidade.

${ }^{39}$ São aqueles destinados a suportar o exercício das funções públicas em caráter instrumental. São afetados ao serviço ou estabelecimento da Administração Pública.

${ }^{40}$ Integram o domínio público exclusivamente para fins patrimoniais. Historicamente, sua finalidade prende-se à função arrecadadora. Modernamente, pretende-se imprimir-lhes um fim instrumental de aplicação de políticas públicas de caráter social-inclusivo.

41 "Nem todos os bens pertencentes ao poder público acham-se direta e imediatamente afetados à realização de um interesse público. Isto é, determinados bens encontram-se prepostos à realização de uma necessidade ou utilidade pública, servindo-a por si mesmos; outros estão afetados a ela de modo instrumental, de maneira que a Administração serve-se deles como um meio, um ambiente físico, no qual, desenvolve atividade pública. Ou seja: correspondem a um local onde o serviço desenvolvido não tem correlação indissociável com a natureza do bem, posto que este nada mais representa senão a base espacial em que se instala, a Administração. Finalmente, outros bens, embora sejam de propriedade pública não estão afetados ao desempenho de um serviço ou atividade administrativa. [...] Certamente existe - partindo-se dos bens dominiais para os de uso comum, tomados como pontos extremos - uma progressiva, crescente, identificação com o interesse público. Os dominiais muito indiretamente beneficiam ou podem beneficiar a utilidade pública; os de uso especial já se apresentam como instrumento para sua efetivação e os de uso comum se identificam com a própria utilidade pública por meio deles expressada”. MELLO, Celso Antonio Bandeira. Desapropriação de bem público. Revista de Direito Público. São Paulo, ano 7, n. 29, p. 47-60, trimestral, 1974.

${ }^{42}$ (Lei n. 10.406, de 10 de janeiro de 2002). Art. 100. Os bens públicos de uso comum do povo e os de uso especial são inalienáveis, enquanto conservarem a sua qualificação, na forma que a lei determinar. Art. 101. Os bens públicos dominicais podem ser alienados, observadas as exigências da lei. BRASIL. Código Civil Brasileiro. Disponível em: < http://www.planalto.gov.br/ccivil_03/leis/2002/110406.htm >. Acesso em: 20 mar. 2012. vo disposição legal em contrário, de inserção do bem no comércio jurídico privado; a imprescritibilidade, traduzida na impossibilidade de sua aquisição por via do usucapião; ${ }^{43}$ e a impenhorabilidade, donde se extrai a impossibilidade de constituição de quaisquer garantias reais sobre o bem público.

Os atributos que gravam a propriedade pública encontram fundamento na premissa, segundo a qual, sendo o interesse público indisponível e considerando os bens públicos como instrumentos para a consecução desse interesse, seriam estes, também, indisponíveis. É o conjunto dos seus atributos que impõe as balizas ao regime de gestão do patrimônio público. Com efeito, a externalidade advinda das características de que se reveste o regime jurídico dos bens públicos predica as condicionantes impostas à forma pela qual deve ser organizado e gerido o acervo público. Esse regime jurídico, derrogatório do direito comum, prevê formas especiais de aquisição, alienação e uso dos bens públicos.

A atividade de gerir o patrimônio público envolve dois aspectos inter-relacionados, de cuja combinação se extrai o respectivo regime:

[...] a gestão patrimonial, entendida como a otimização do emprego do patrimônio público, com vistas a obter a maior racionalidade econômica, e a disciplina do uso, voltada a assegurar que este emprego seja consentâneo com as finalidades de interesse geral às quais o bem está consagrado. $^{44}$

Com efeito,

[...] a gestão dos bens públicos, como retrata típica atividade administrativa, é regulada normalmente por preceitos legais genéricos e por normas regulamentares mais específicas. A alienação, a oneração e a aquisição reclamam, como regra, autorização legal de caráter mais específico, porque na hipótese não há mera administração, mas alteração na esfera do domínio das pessoas de direito público. ${ }^{45}$

Nesse cenário, a gestão dos bens públicos é a atividade administrativa mais evidente, situando-se mesmo

${ }^{43}$ (Lei n. 10.406, de 10 de janeiro de 2002). Art. 102. bens públicos não estão sujeitos a usucapião. BRASIL. Código Civil Brasileiro. Disponível em < http://www.planalto.gov.br/ccivil_03/ leis/2002/110406.htm >. Acesso em: 20 mar. 2012.

${ }^{44}$ MARQUES NETO, Floriano de Azevedo. Bens públicos: função social e exploração econômica: regime jurídico das utilidades públicas. Belo Horizonte: Fórum, 2009.

${ }^{45}$ CARVAlHO FILHO, José dos Santos. Manual de direito administrativo. 15. ed. Rio de Janeiro: Lumen Juris, 2006. p. 843. 
no âmago da função administrativa das pessoas de direito público. Daí subtrai-se a necessidade de empreender, nesta seara, severa diligência, tendo-se sempre presente que um bem que integra o acervo de uma pessoa de direito público, em última análise, pertence à própria coletividade.

Sobressai nítido que a atividade de gerir os bens públicos enseja incontáveis providências, pertinentes à sua conservação, finalidade, proteção e utilização. Este último tópico, utilização dos bens públicos, será objeto de análise pormenorizada. A par de serem utilizados pela pessoa de direito público a que pertencem, titular do respectivo domínio, os bens públicos podem ser utilizados por terceiros, hipótese em que o Estado o autoriza expressamente. Nesse caso, a finalidade pública do uso pode não ser ostensiva, mas ainda que indiretamente, será o elemento mobilizador do consentimento estatal. ${ }^{46}$

A gestão do acervo público deverá sempre ser orientada pelos vetores constitucionais aplicáveis à Administração Pública, bem como pelo princípio da função social da propriedade. Assim, a atividade de gerir o patrimônio público deve ser entendida como um poder-dever do administrador orientado pela busca da otimização, racionalização e ampliação do uso dos bens públicos, cuidando para que representem uma utilidade efetiva para a coletividade, e não apenas sob a perspectiva de sua conservação e gestão com base no mero valor de troca.

\subsection{O uso dos bens públicos pelos particulares}

Daí advém a importância do regime de outorga do uso do patrimônio público aos particulares. ${ }^{47} \mathrm{O}$ uso de

${ }^{46}$ DI PIETRO, Maria Sylvia Zanella. Direito administrativo. 24. ed. São Paulo: Atlas, 2011.

47 "A atividade de consenso-negociação entre poder público e particulares, mesmo informal, passa a assumir papel importante no processo de identificação e definição de interesses públicos e privados tutelados pela Administração. A Administração Pública deixa de deter a exclusividade no estabelecimento do interesse público; a discricionariedade se reduz, atenua-se a prática de imposição unilateral e autoritária das decisões. A Administração volta-se para a coletividade, passando a conhecer melhor os problemas e aspirações da sociedade. A Administração passa a ter a atividade de mediação para dirimir e compor conflitos de interesses entre as várias partes ou entre estas e a Administração. Daí decorre um novo modo de agir, não mais centrado sobre o ato como instrumento exclusivo de definição do interesse público, mas como atividade aberta à colaboração dos indivíduos. Passa a ter relevo o momento do consenso e da participação". MEDAUAR, Odete. Direito administrativo em evolução. São Paulo: Revista dos Tribunais, 2003. bens públicos por particulares divide-se em uso comum e uso especial. O uso comum incide sobre bens que servem à utilização coletiva, como ocorre em regra com os bens de uso comum do povo: praias, ruas, avenidas, praças públicas e logradouros públicos. São suas características: $1^{\mathrm{a}}$ ) a generalidade da utilização do bem; $2^{\mathrm{a}}$ ) o uso indiscriminado pelos administrados; $3^{\text {a }}$ ) a adequação do uso aos fins normais a que o bem se destina; e $4^{\text {a }}$ ) a ausência de gravame imposto para o uso. ${ }^{48}$

A utilização do bem de uso comum independe de qualquer titulação específica. Seu exercício decorre da própria destinação que ostenta o bem, prescindindo de qualquer ato administrativo prévio ou dever de comunicação à autoridade acerca da intenção de utilizá-lo. O uso especial é a utilização fundada em consentimento administrativo expresso e geralmente encerra alguns efeitos singulares para o particular, como a exclusividade do uso e a onerosidade. Quando revestido da nota da exclusividade, consoante o título outorgado pelo Estado, o uso do bem passa a ser entendido como uso especial privativo.

A utilização privativa do patrimônio público pode recair sobre bens de qualquer natureza: de uso comum, de uso especial, ou dominicais. O uso especial dá ensejo a diferentes modalidades de instituto, uns sujeitos a regras especiais de direito público (tratando-se de bens de uso comum do povo e de uso especial), como a concessão de uso, a concessão de direito real de uso, a autorização de uso, a cessão de uso, e a permissão de uso, e outros regulados basicamente por normas de direito privado, como, por exemplo, a locação, o comodato e a enfiteuse (estes aplicáveis aos bens dominicais). ${ }^{49}$

Impende consignar que são competentes para conferir as respectivas outorgas de uso de bens do patrimônio público os órgãos da pessoa coletiva de direito público titular do domínio do bem, ou a quem estiver confiada a respectiva gestão. Assim, “[...] licenças e concessões são atos que se fundam no direito de disposição do proprietário". ${ }^{50}$ Resta forçoso ponderar, portanto, que

${ }^{48}$ CARVALHO FILHO, José dos Santos. A autorização de uso de bem público de natureza urbanística. Disponível em: <http:// www.mundojuridico.adv.br>. Acesso em: 20 mar. 2012

${ }^{49}$ CARVALHO FILHO, José dos Santos. A autorização de uso de bem público de natureza urbanística. Disponível em: <http:// www.mundojuridico.adv.br>. Acesso em: 20 mar. 2012

${ }^{50}$ CAETANO. Marcello. Manual de direito administrativo. Rio de Janeiro: Forense, 1970. 
não há um regime jurídico único de outorga do uso dos bens públicos, aplicável à totalidade do patrimônio público. Deveras, no Direito Brasileiro, que prestigia o regime federativo, cada esfera de governo tem competência para legislar sobre a gestão dos bens que lhes são atinentes. ${ }^{51}$

Por via da Autorização de Uso é consentida ao particular a prática de determinada atividade individual incidente sobre um bem público, por via da edição de um ato administrativo, discricionário e precário. ${ }^{52}$ Prescinde de forma ou requisitos especiais para a sua efetivação, posto que sua finalidade esgota-se na outorga de permissão para a prática de atividades transitórias e irrelevantes para o Poder Público. Consubstancia-se em ato escrito, revogável sumariamente a qualquer tempo, e sem ônus para a Administração.

A Cessão de Uso é o ato unilateral de transferência gratuita de posse de um bem público de uma entidade ou órgão da Administração Pública para outro, dentre as diversas esferas de governo, por tempo certo ou indeterminado. É ato administrativo que se reveste do cariz de colaboração entre repartições públicas. Já a Permissão de Uso "[...] é o ato unilateral pelo qual a Administração faculta precariamente a alguém a utilização especial de um bem público". ${ }^{53}$ Em outras palavras:

Permissão de uso é ato negocial unilateral, discricionário e precário através do qual a Administração faculta ao particular a utilização individual de determinado bem público. Como ato negocial, pode ser com ou sem condições, gratuito ou remunerado, por tempo certo ou indeterminado, conforme estabelecido no termo próprio, mas sempre modificável e revogável unilateralmente pela Administração, quando o interesse público o exigir, dados sua natureza precária e o poder discricionário do permitente para consentir e retirar o uso especial do bem público. $^{54}$

Impende consignar que a nota da precariedade que se lança sobre a permissão de uso legitima a Administração Pública, com fundamento no interesse público, concedê-la e retirá-la discricionariamente sem que para

${ }^{51}$ DI PIETRO. Maria Sylvia Zanella. Uso privativo de bem público por particular. São Paulo: Revista dos Tribunais, 1983.

52 SILVA, José Afonso. Comentário contextual à Constituição. 7. ed. São Paulo: Malheiros, 2010.

${ }^{53}$ MELLO, Celso Antônio Bandeira. Curso de direito administrativo. 25. ed. São Paulo: Malheiros, 2008. p. 388.

${ }^{54}$ MEIRELLES, Hely Lopes. Direito administrativo brasileiro. 33. ed. São Paulo: Malheiros, 2007. p. 466. isso tenha dever de indenização ao permissionário. ${ }^{55}$ Tem-se que:

[...] a permissão de uso é caracterizada pela precariedade do vínculo que estabelece. Apesar de conferir direitos aos outorgados contra terceiros (a exclusividade no uso dos bens públicos), não estabelece direitos frente à Administração - por isso é precária, podendo, a qualquer tempo, ser revogada por razões de interesse público, sem qualquer violação à esfera de direitos dos particulares. ${ }^{56}$

Com efeito,

O regime permissional, menos rígido, tem sido caracterizado na doutrina tradicional como vínculo produzido por simples manifestação de vontade unilateral da Administração, através de um ato administrativo, discricionário e precário, que seria, por isso revogável a qualquer tempo. ${ }^{57}$

Assim, quando o uso do bem, comportado em suas destinações secundárias, compatível, portanto, com sua destinação principal e até mesmo propiciando uma serventia para a coletividade, implicar ocupação de parte dele com caráter de exclusividade em relação ao uso propiciado pela sobredita ocupação, revestida de caráter precário, sua utilização estará sujeita à permissão de uso de bem público. É o caso de quiosques para venda de cigarros ou refrigerantes, de bancas de jornal, ou de utilização das

${ }^{55}$ BRASIL. Superior Tribunal de Justiça. RMS 16280 / RJ. Diário de Justiça. Brasília, 19 abr. 2004. "Processual Civil. Recurso Ordinário em Mandado de Segurança. Ato Administrativo. Permissão de uso de imóvel municipal por particular. Natureza precária e discricionária. Possibilidade de cancelamento. Previsão contratual. Ausência de direito líquido e certo. 1. A autorização de uso de imóvel municipal por particular é ato unilateral da Administração Pública, de natureza discricionária, precária, através do qual esta consente na prática de determinada atividade individual incidente sobre um bem público. Trata-se, portanto, de ato revogável, sumariamente, a qualquer tempo, e sem ônus para o Poder Público. 2. Como a Administração Pública Municipal não mais consente a permanência da impetrante no local, a autorização perdeu sua eficácia. Logo, não há direito líquido e certo a ser tutelado na hipótese dos autos. 3. Comprovação nos autos da existência de previsão contratual no tocante ao cancelamento da permissão debatida. 4. Recurso não provido."

${ }^{56}$ SUNDFELD, Carlos Ari; CÂMARA, Jacintho de Arruda. Concessão de direito real de uso de utilidade pública - Possibilidade de o poder público conferir a particular a gestão exclusiva de seu bens para fins de utilidade pública. Hipótese em que a outorga independerá de licitação, por ser esta inexigível. Boletim de licitações e contratos, São Paulo, v. 10, n. 12, p. 593-602, mensal, 1997.

${ }_{57}$ MOREIRA NETO, Diogo de Figueiredo. Curso de direito administrativo. 15. ed.. Rio de Janeiro: Forense, 2009. p. 264. 
calçadas para colocação de mesinhas diante de bares ou restaurantes. ${ }^{58}$

A fim de extremar os conceitos de autorização de uso e permissão de uso, pondera-se que a autorização traduz-se em uma faculdade de uso privativo no interesse privado do beneficiário, enquanto a permissão implica na utilização privativa para fins de interesse coletivo, e, por isso, só deve ser outorgada quando dela resultar atendimento de algum interesse público; a nota da precariedade é mais acentuada na autorização; e a autorização gera para o usuário uma faculdade, enquanto a permissão implica em obrigação, sob pena de caducidade do uso consentido. $^{59}$

Concessão de uso é o contrato administrativo pelo qual o Poder Público atribui a utilização exclusiva de um bem de seu domínio a particular, para que o explore segundo sua destinação específica. A concessão pode ser remunerada ou gratuita, por tempo certo ou indeterminado, mas deverá ser sempre precedida de autorização legal e, normalmente, de concorrência para o contrato. ${ }^{60}$ Sua outorga não é nem discricionária nem precária, e tem a estabilidade relativa dos contratos administrativos, gerando direitos individuais e subjetivos para o concessionário. O Direito Brasileiro prevê três modalidades de concessão de uso: a concessão simples ou administrativa, a concessão de direito real de uso ${ }^{61} \mathrm{e}$ a concessão especial para fins de moradia. ${ }^{62}$

A concessão de uso não se confunde com a concessão de direito real de uso que é o contrato pelo qual a Administração transfere o uso, remunerado ou gratuito, de

${ }_{58}$ MELLO, Celso Antônio Bandeira. Curso de direito administrativo. 25. ed. São Paulo: Malheiros, 2008.

${ }^{59}$ DI PIETRO. Maria Sylvia Zanella. Uso privativo de bem público por particular. São Paulo: Revista dos Tribunais, 1983.

${ }^{60}$ RIGOLIN, Ivan Barbosa. Concessão, permissão, autorização, cessão e doação: quais as diferenças? In: FÓRUM DE CONTRATAÇÃO E GESTÃO PÚBLICA, 2004, Belo Horizonte. Belo Horizonte: Fórum, 2004.

${ }^{61}$ BRASIL. Decreto-Lei no 271/67. Disponível em < http://www. planalto.gov.br/ccivil_03/decreto-lei/del0271.htm >. Acesso em: 20 mar. 2012.

${ }^{62}$ Em 2001, com a aprovação do Estatuto da Cidade e da Medida Provisória n. 2.220, os instrumentos da concessão de direito real de uso e da concessão de uso especial para fins de moradia são consolidados como instrumentos de regularização fundiária de interesse social. Em 2007, passam a integrar os direitos reais expressos no Código Civil, com as alterações promovidas pela Lei n. 11.481, de 31 de maio de 2007. terreno público a particular, como direito real resolúvel, ${ }^{63}$ para que dele se utilize em fins específicos de urbanização, industrialização, edificação, cultivo ou qualquer outra exploração de interesse social. A concessão de direito real de uso pode ser outorgada por escritura pública ou termo administrativo e é transferível a terceiros, ${ }^{64}$ devendo o concessionário responder por todos os encargos civis, administrativos e tributários que venham a incidir sobre o imóvel e suas respectivas rendas.

A concessão especial para fins de moradia assemelha-se à concessão de direito real de uso, posto conferir ao concessionário um direito de uso estável, transferível a terceiros. Seu traço distintivo reside em sua finalidade exclusiva: a moradia do concessionário e sua família, finalidade esta que perdurará por todo o período da concessão, outorgada em caráter perpétuo. Sua outorga, sempre a título gratuito, somente poderá recair em terreno urbano, excluindo bens de uso comum e algumas classes de bens de uso especial. ${ }^{65} \mathrm{O}$ que caracteriza a concessão de uso (em sentido amplo) e a distingue dos demais institutos assemelhados - autorização e permissão de uso - é o caráter contratual e estável da outorga do uso do bem público ao particular, para que o utilize com exclusividade e nas condições convencionadas com a Administração.

A concessão de uso, por vezes, envolve a outorga conjugada do exercício de uma determinada atividade pública, hipótese em que o concessionário atua como de-

${ }^{63}$ BRASIL. Decreto-Lei no 271/67. Disponível em < http://www. planalto.gov.br/ccivil_03/decreto-lei/del0271.htm >. Acesso em: 20 mar. 2012. Art. 7º É instituída a concessão de uso de terrenos públicos ou particulares remunerada ou gratuita, por tempo certo ou indeterminado, como direito real resolúvel, para fins específicos de regularização fundiária de interesse social, urbanização, industrialização, edificação, cultivo da terra, aproveitamento sustentável das várzeas, preservação das comunidades tradicionais e seus meios de subsistência ou outras modalidades de interesse social em áreas urbanas. [...] $\$ 3^{\circ}$ Resolve-se a concessão antes de seu têrmo, desde que o concessionário dê ao imóvel destinação diversa da estabelecida no contrato ou têrmo, ou descumpra cláusula resolutória do ajuste, perdendo, neste caso, as benfeitorias de qualquer natureza.

${ }^{64}$ BRASIL. Decreto-Lei no 271/67. Disponível em < http://www. planalto.gov.br/ccivil_03/decreto-lei/del0271.htm >. Acesso em: 20 mar. 2012. Art. $7^{\circ}$. [...] $\$ 4^{\circ}$ A concessão de uso, salvo disposição contratual em contrário, transfere-se por ato inter vivos, ou por sucessão legítima ou testamentária, como os demais direitos reais sobre coisas alheias, registrando-se a transferência.

${ }^{65}$ Por exemplo, imóveis funcionais, imóveis de interesse da defesa nacional etc. 
legado do Poder Público, incumbido do desempenho de um serviço de utilidade pública. Nesse caso, a outorga do uso do bem público é assessória ao cometimento principal, posto que o direito de exploração da atividade trará, subjacente, o direito de uso privativo dos respectivos bens a ela afetos. Na situação em que a concessão tem por objeto exclusivamente a outorga do direito de uso do bem, o objeto contratual é o próprio uso. Essa diferenciação de objetos traduz a necessidade de observância a regimes jurídicos específicos para cada caso.

Deveras, a fim de bem delimitar a questão atinente ao regime jurídico aplicável às concessões de uso de bem público, faz-se necessário fixar a distinção entre os instrumentos de concessão de serviço público e de uso bem público, institutos que não se confundem, e que, por isso mesmo, merecem tratamento jurídico diverso. A concessão de serviço público é:

\begin{abstract}
[...] instituto por meio do qual o Estado atribui o exercício de um serviço público a alguém que aceite prestá-lo em nome próprio, por sua conta e risco, nas condições fixadas e alteráveis unilateralmente pelo Poder Público, mas sob a garantia contratual de um equilíbrio econômico-financeiro, remunerando-se pela própria exploração do serviço, em geral mediante tarifas cobradas diretamente dos usuários. ${ }^{66}$
\end{abstract}

Sua natureza prende-se com a de um ato jurídico que amplia a esfera jurídica do particular, conferindo-lhe um direito novo, relativo à execução de uma atividade pública. Nesse contexto, é um instrumento de descentralização da prestação de serviços públicos. Com efeito, sendo o Poder Público titular de determinada atividade, pode, no entanto, promover-lhe a prestação (que é um dever em relação aos serviços postos a seu cargo pela lei ou pela Constituição), conferindo-a a entidades estranhas ao seu aparelho administrativo, mediante a outorga de titulação para que a desempenhe. Ou seja, poderá conferir permissão ou concessão a fim de que seja executada por tais pessoas. ${ }^{67}$

Distingue-se da concessão de uso de bem público, porquanto, nela não há exercício de atividade pública pelo concessionário, que adquire o direito de utilizar determinada parcela do domínio público com vistas ao de-

\footnotetext{
${ }^{66}$ MELLO, Celso Antonio Bandeira. Curso de direito administrativo. 25. ed. São Paulo: Malheiros, 2008. p. 631.

${ }^{67}$ MELLO, Celso Antonio Bandeira. Serviço público: conceito e características. Biblioteca Jurídica Virtual Del Instituto de Investigaciones Jurídicas de la UNAM. Disponível em: <www. juridicas.unam.mx>. Acesso em: 20 mar. 2012.
}

senvolvimento de uma atividade de fins primacialmente privados, e somente mediatamente pertinentes à satisfação de uma finalidade pública. Constituindo realidades jurídicas distintas, é natural que as concessões de serviço público e de uso de bem público se submetam a regimes jurídicos diversos. Deveras, a outorga de prestação de serviço público mereceu enfoque constitucional, diversamente da concessão e permissão de uso de bem público, sobre as quais, a Constituição Federal de 1988 quedou-se silente..$^{68}$

Também, no contexto infraconstitucional, o tratamento legal não se assemelha. Com efeito, o legislador federal editou diploma legal voltado ao regramento das concessões e permissões de serviço público, estabelecendo pormenorizado regime jurídico aplicável aos referidos institutos. ${ }^{69}$ Tal norma não cuida do regime a ser aplicado quando da outorga de uso de bens públicos. Impende consignar que há, nada obstante, respeitável posição doutrinária que admite a possibilidade de aplicação subsidiária da Lei $n^{\circ} 8.987 / 95$ às concessões de uso, conquanto seja tal norma voltada a reger a concessão de serviços. ${ }^{70}$

Quanto à submissão às normas estabelecidas na Lei de Licitações (Lei no 8.666/93), no entanto, verifica-se a convergência doutrinária (majoritária) e jurisprudencial no sentido da sua aplicabilidade indistinta às concessões de serviço público e de uso de bem público, salvaguardando do comando legal somente as permissões de uso. Tal tópico será objeto de análise mais detida.

${ }^{68}$ BRASIL. Constituição (1988). Constituição da República Federativa do Brasil. Brasília: Congresso Nacional, 1988. "Art. 175. Incumbe ao Poder Público, na forma da lei, diretamente ou sob regime de concessão ou permissão, sempre através de licitação, a prestação de serviços públicos.

Parágrafo único. A lei disporá sobre:

I - o regime das empresas concessionárias e permissionárias de serviços públicos, o caráter especial de seu contrato e de sua prorrogação, bem como as condições de caducidade, fiscalização e rescisão da concessão ou permissão;

II - os direitos dos usuários;

III - política tarifária;

IV - a obrigação de manter serviço adequado".

${ }^{69}$ BRASIL. Lei $n^{\circ}$ 8.987, de 13 de fevereiro de 1995. Disponível em: <http://www.planalto.gov.br/ccivil_03/leis/18987cons. htm>. Acesso em: 20 mar. 2012. "Art. $1^{\circ}$ As concessões de serviços públicos e de obras públicas e as permissões de serviços públicos reger-se-ão pelos termos do art. 175 da Constituição Federal, por esta Lei, pelas normas legais pertinentes e pelas cláusulas dos indispensáveis contratos".

${ }^{70}$ MARQUES NETO, Floriano de Azevedo. Bens públicos: função social e exploração econômica: o regime jurídico das utilidades públicas. Belo Horizonte: Fórum, 2009. 


\section{Regime jurídico aplicável às concessões e permissões de uso de bens públicos}

\subsection{Aplicabilidade da lei de licitações às outorgas de uso de bens públicos}

A Lei de Licitações (Lei n. 8.666/93) alberga diretrizes para balizar os processos de contratação de bens e serviços no âmbito da Administração Pública Brasileira. Em seu bojo, inserem-se normas a serem observadas pelo Poder Público, nas esferas federal, estadual e municipal. Com efeito,

Licitação é um procedimento administrativo destinado a provocar propostas e escolher proponentes de contratos de execução de obras, serviços, compras ou de alienações do Poder Público. O princípio da licitação significa que essas contratações ficam sujeitas, como regra, ao procedimento de seleção de propostas mais vantajosas para a Administração Pública. Constitui um princípio instrumental de realização dos princípios da moralidade administrativa e do tratamento isonômico dos eventuais contratantes com o Poder Público. ${ }^{71}$

Sua finalidade precípua é satisfazer uma necessidade da Administração Pública, atinente à execução de obras, serviços, aquisição ou alienação de bens, móveis ou imóveis. A adequação traduz-se no pressuposto da licitação. Em outras palavras, o procedimento licitatório pressupõe a existência de um mercado diversificado, seja em relação ao objeto pretendido pela Administração, seja em relação ao número de prestadores de serviços ou fornecedores de bens, porquanto, inexistindo pluralidade em qualquer desses fatores, não há que se falar em licitação.

A vigente Constituição Federal exige que a concessão ou permissão de serviço público seja sempre precedida de licitação pública. É o que dispõe expressamente seu art. 175:"Incumbe ao Poder Público, na forma da lei, diretamente ou sob regime de concessão ou permissão, sempre através de licitação, a prestação de serviços públicos".

Relativamente às permissões destinadas à outorga de uso de bem público, o regime jurídico parece ser diverso. Deveras, estabelece o art. $2^{\circ}$, da Lei $n^{\circ}$ 8.666/93: "As obras, serviços, inclusive de publicidade, compras, alienações, concessões, permissões e locações da Administração Pública, quando contratadas com terceiros, serão

\footnotetext{
${ }^{71}$ SILVA, José Afonso. Curso de direito constitucional positivo. 34. ed. São Paulo: Malheiros, 2011. p. 672.
}

necessariamente precedidas de licitação, ressalvadas as hipóteses previstas nesta Lei"72.

A partir desse dispositivo legal, é possível proceder à análise da aplicabilidade desse diploma legal relativamente às outorgas de uso de bem públicos a particulares.

\subsection{Aplicabilidade da lei de licitações às permissões de uso de bens públicos}

Pela redação do dispositivo transcrito, é possível concluir que as permissões efetuadas pela Administração Pública somente estariam sujeitas às regras da licitação quando sua formalização for realizada por via de contrato. É o caso, como visto, das permissões de serviço público ${ }^{73}$ contempladas pelo art. 175 da Constituição Federal. Ocorre que as permissóes de uso de bem público, em regra, manifestam-se por meio de ato administrativo unilateral, discricionário e precário. Nesse contexto, subtrai-se que tais permissões não são alcançadas pelo citado $\operatorname{artigo~} 2^{\circ}$, da Lei de Licitações.

Segundo a dicção do art. 37, inciso XXI, c/c com o art. 22, inciso XXVII, ambos da Constituição Federal, a licitação não é direcionada a atos precários, celebrados por meio de termo, sem as garantias do contrato administrativo. Cotejados esses dispositivos constitucionais com o mencionado art. $2^{\circ}$, da Lei no $8.666 / 93$, situações precárias como as permissões de uso de bem público, outorgadas mediante ato administrativo unilateral, discricionário e precário, parecem extremadas da observância obrigatória do procedimento licitatório. Com efeito, a leitura dos preceitos legais em comento revela que somente as permissões voltadas para a prática de serviços públicos, com estipulações de obrigações recíprocas, é que deveriam ser precedidas de licitação.

A permissão de uso de bem público, não ostentando natureza contratual, resta excluída da necessidade de observância obrigatória do prévio certame licitatório:

\footnotetext{
${ }^{72}$ BRASIL. Lei n. 8.666 de 21 de junho de 1993, Art. $2^{\circ}$. Disponível em: < http://www.planalto.gov.br/ccivil_03/leis/ 18666cons.htm>. Acesso em: 20 mar. 2012.

${ }^{73}$ BRASIL. Lei n. 8.987/95: Art. 2º. Disponível em: <http://www. planalto.gov.br/ccivil_03/leis/18987cons.htm>. Acesso em: 20 mar. 2012. Para os fins do disposto nesta Lei, considera-se: IV- permissão de serviço público: a delegação, a título precário, mediante licitação, da prestação de serviços públicos, feita pelo poder concedente à pessoa física ou jurídica que demonstre capacidade para seu desempenho, por sua conta e risco.
} 
O instituto da permissão, na doutrina brasileira, tem sido definido como ato unilateral e não como contrato. No entanto, a Constituição Federal, ao tratar da concessão e da permissão do serviço público, referiu-se a ambos como contrato (art. 175, parágrafo único, inc. I) e foi expresso na exigência de licitação (caput do mesmo dispositivo). Também o art. 124, da Lei no 8.666 , introduzido pela Lei $\mathrm{n}^{\circ} 8.883$, refere-se à permissão de serviço público como contrato. Assim sendo, não há dúvida de que a permissão de serviço público está sujeita aos ditames da Lei $n^{\circ}$ 8.666. Já a permissão de uso constitui, em regra, ato unilateral e, como tal, não se enquadra na exigência do art. $2^{\circ}$, que, ao mencionar as várias modalidades (obras, compras, alienações, concessões, permissões e locações), acrescenta a expressão 'quando contratados com terceiros'. [...] A permissão de uso, quando dada precariamente (como é de sua natureza), ou seja, sem prazo estabelecido, não cria obrigações para a Administração Pública, que concede a permissão e a retira discricionariamente, independentemente do consentimento do permissionário, segundo razões exclusivamente de interesse público. Nesses casos, a permissão não tem natureza contratual e, portanto, não está sujeito à licitação. ${ }^{74}$

Tem-se, portanto, que a permissão de uso de bem público, estabelecida de forma precária e sem prazo de duração, fica excluída da Lei no 8.666/93 (Lei de Licitações), tendo em vista que a sua natureza jurídica se atrela à discricionariedade da Administração Pública na destinação da utilização de determinado bem público.

Nada obstante, convém esclarecer que existem as permissões de uso qualificadas, caracterizadas pela previsão de realização de benfeitorias por parte do permissionário, com estipulação do prazo de sua vigência. A doutrina pontua que a fixação de tal prazo mitigaria a precariedade do ato, tornando-o assemelhado à concessão de uso. Assim, predomina o entendimento, segundo o qual, nas permissões qualificadas seria obrigatória a observância do prévio procedimento licitatório. Sofreriam, portanto, a incidência do art. $2^{\circ}$ da Lei de Licitações. ${ }^{75}$ Para que isso se verifique, impõe-se que a permissão de uso tenha prazo estabelecido, circunstância que pode gerar para o particular o direito à percepção de indenização em caso de revogação da permissão antes do prazo estabelecido. Nesse caso, a permissão de uso deveria sujeitar-se à licitação.

\footnotetext{
${ }^{74}$ DI PIETRO, Maria Sylvia Zanella. Temas polêmicos sobre licitações e contratos. 5. ed. São Paulo: Malheiros Editores, 2006. p. 215.

${ }^{75}$ DI PIETRO, Maria Sylvia Zanella. Direito administrativo. 24. ed. São Paulo: Atlas, 2011.
}

Com efeito, a Lei $n^{\circ} 8.666 / 93$ parece ter em vista precisamente situações como esta, quando, no artigo $2^{\circ}$, parágrafo único, define o contrato como "[...] todo e qualquer ajuste entre órgãos ou entidades da Administração Pública e particulares, em que haja um acordo de vontades para a formação de vínculo e a estipulação de obrigações recíprocas, seja qual for a denominação utilizada"76. Assim, para essa corrente doutrinária, hoje amparada em entendimento jurisprudencial, ainda que se refira à permissão, a licitação seria obrigatória se ela se revestir da forma contratual. ${ }^{77}$ Assim, a permissão é, em princípio, discricionária e precária, embora, em certos casos, admita condições e prazos para exploração do serviço a fim de garantir rentabilidade e assegurar a recuperação do investimento do permissionário, visando atrair a iniciativa privada.

Não se revestindo da forma contratual, a permissão instrumentaliza-se por meio de ato unilateral, precário e discricionário da Administração Pública, hipótese em que poderá ser outorgada sem observância das regras de concorrência. Nesse contexto, a permissão de uso especial de bem público, como ato unilateral e precário, é ordinariamente deferida independentemente de lei autorizativa ou de prévio procedimento licitatório.

${ }^{76}$ BRASIL. Lei n. 8.666 de 21 de junho de 1993, Art. $2^{o}$. Disponível em: < http://www.planalto.gov.br/ccivil_03/leis/ 18666cons.htm>. Acesso em: 20 mar. 2012.

77 BRASIL. Tribunal de Contas da União. Revista do TCU, v. 38, n. 108, jan/abr de 2007. Disponível em: < http://portal2.tcu. gov.br/portal/pls/portal/docs/2054060.PDF > . Acesso em: 20 mar. 2012. "No que concerne à obrigatoriedade de realização de licitação para a outorga em comento, importa salientar que a permissão de uso de bem público, pelas suas características, está excluída da exigência do art. $2^{\circ}$ do Estatuto de Licitações, pelas definições ali contidas, especialmente a do seu parágrafo único que, ao definir contrato, estabelece: "Para os fins desta Lei, considera-se contrato todo e qualquer ajuste entre órgãos ou entidades da Administração Pública e particulares, em que haja um acordo de vontades para a formação de vínculo e a estipulação de obrigações recíprocas, seja qual for a denominação utilizada." Com efeito, a permissão, concedida a título precário, não cria obrigações para a Administração Pública, que a concede e a retira, estritamente em razão de interesse público, e sem que haja necessidade de consentimento do permissionário. Nesses casos, como a permissão de uso não tem natureza contratual, preleciona a administrativista Maria Sylvia Zanella di Pietro (Temas Polêmicos sobre Licitações e Contratos, Malheiros Editores, 2a ed., 1995): “[... ] não está abrangida pela Lei no 8.666/93, o que não impede a Administração de fazer licitação ou instituir outro processo de seleção, sempre recomendável quando se trata de assegurar igualdade de oportunidade a todos os eventuais interessados". 
Em síntese, ao revestir-se de natureza negocial, com estipulação de obrigações recíprocas e previsão de condições, como prazo de vigência, a permissão desnatura-se, despindo-se da nota de precariedade de que ordinariamente se reveste. Nessa hipótese, ainda que ostente o nome de permissão de uso de bem público, sua essência é contratual, o que imporia, na perspectiva acima abordada, a obrigatoriedade da aplicação das regras concorrenciais previstas na Lei de Licitações. Do contrário, inexistindo estipulação de obrigações recíprocas, o ato de permissão subjaz precário, unilateral, cuja outorga insere-se no poder discricionário do gestor público e sua revogação não tem o condão de propiciar qualquer recomposição financeira ao particular permissionário.

Nada obstante à plausibilidade da argumentação doutrinária, resta forçoso ponderar acerca de algumas questões referentes ao regime jurídico aplicável às concessões de uso de bens públicos por particulares.

\subsection{Aplicabilidade da lei de licitações às concessões de uso de bens públicos}

Por primeiro, impende notar que, restando excluída do comando extraído do art. 175 do Texto Constitucional, a outorga de uso de bem público deve assentar em fundamento diverso daquele que empresta suporte à concessão de serviço público. Sua delimitação passa necessariamente por uma incursão nos limites constitucionais impostos à competência legislativa ${ }^{78}$ de cada ente federado para o estabelecimento de regimes atinentes ao uso dos bens do patrimônio público. Consoante já salientado, a Constituição Federal de 1988 não cuidou da matéria relativa à outorga, aos particulares, do uso de bens do domínio público, tampouco lhe impôs a observância a regras de concorrência, deixando livre o legislador ordinário para estabelecer o respectivo regime jurídico.

Nesse cenário, a partir da interpretação da Lei de Licitações, doutrina e jurisprudência acabaram por se inclinar no sentido de sua aplicabilidade às concessões de uso de bem público, enquanto instrumentos contratuais

\footnotetext{
78 "Competência é a faculdade juridicamente atribuída a uma entidade ou a um órgão ou agente do Poder Público para emitir decisões. As competências são atribuídas aos diversos agentes do Poder Público sob a égide de separação de poderes (legislativo, executivo e judiciário) e divisão de funções do poder (especialização de tarefas governamentais à vista de sua natureza)". SILVA. José Afonso. Curso de direito constitucional positivo. 34. ed. São Paulo: Malheiros, 2011.
}

de outorga do uso de parcela do domínio público a particulares, conquanto, entendam que as permissões de uso estariam infensas à Lei $n^{\circ} 8.666 / 93$. Assim, sob essa perspectiva, a interpretação dada ao caput do art. $2^{\circ}$, da Lei n ${ }^{\circ}$ 8.666/93, em cotejo com o que dispõe o parágrafo único do mesmo dispositivo, conduz ao entendimento, segundo o qual, todas as concessões, sejam elas de serviços públicos, obras ou uso de bens públicos, estariam, porquanto necessariamente revestem-se de forma contratual e só por isso, sujeitas aos comandos exarados pela Lei de Licitações. A matéria, entretanto, comporta entendimento diverso.

Para bem elucidar a questão posta, convém proceder à correta exegese do art. $2^{\circ}$, da Lei n. 8.666/93. ${ }^{79} \mathrm{~A}$ leitura perfunctória do referido dispositivo legal conduz ao entendimento segundo o qual "[...] todo e qualquer ajuste entre órgãos ou entidades da Administração Pública e particulares, em que haja um acordo de vontades para a formação de vínculo e a estipulação de obrigações recíprocas, seja qual for a denominação utilizada" ${ }^{30}$, em qualquer caso, ainda em se tratando de matéria afeta à outorga do uso de bens públicos a particulares, estaria sujeito às normas de Licitação. Ocorre que, em uma análise mais criteriosa, sobressai nítido que a Lei 8.666 /93 foi vocacionada ao regramento de questões atinentes às obras, serviços, inclusive de publicidade, compras, alienações e locações, consoante resta explicitado in litteris no seu art. $1^{\circ}$ :

Art. $1^{\circ}$ Esta Lei estabelece normas gerais sobre licitações e contratos administrativos pertinentes a obras, serviços, inclusive de publicidade, compras, alienações e locações no âmbito dos Poderes da União, dos Estados, do Distrito Federal e dos Municípios. ${ }^{81}$

Tal vocação exsurge ainda mais evidente quando se examina todo o texto legal em comento. Com efeito, inexiste qualquer dispositivo na Lei de Licitações que se refira à outorga de uso de bem público. Revela-se, inclusi-

${ }^{79}$ BRASIL. Lei n. 8.666/93. Art. 20. Disponível em: < http:// www.planalto.gov.br/ccivil_03/leis/18666cons.htm>. Acesso em: 20 mar. 2012. As obras, serviços, inclusive de publicidade, compras, alienações, concessões, permissões e locações da Administração Pública, quando contratadas com terceiros, serão necessariamente precedidas de licitação, ressalvadas as hipóteses previstas nesta Lei.

${ }^{80}$ BRASIL. Lei $n$. 8.666/93. Disponível em: <http://www.planalto.gov.br/ccivil_03/leis/18666cons.htm>. Acesso em: 20 mar. 2012.

${ }^{81}$ BRASIL. Lei n. 8.666/93. Disponível em: <http://www.planalto.gov.br/ccivil_03/leis/18666cons.htm>. Acesso em: 20 mar. 2012. 
ve, sua total inaptidão para conferir esteio a processo administrativo tendente a este fim. Nesse contexto, pode-se concluir que a Lei no 8.666/93 não pretende, como de fato não o faz, regular o regime jurídico pertinente às concessões de uso de bem público.

\subsection{Aplicabilidade da lei de licitações às concessões de uso de bens públicos municipais}

Tendo em vista o disposto no art. 30 da Constituição Federal, a matéria atinente às outorgas de uso de bens públicos pode ser inserida na competência local, ${ }^{82} \mathrm{em}$ se tratando de bens de propriedade municipal, ou estadual, se tratar de patrimônio do Estado.

Nesse tópico sobreleva notar que:

[...] peculiar interesse, ou assunto de interesse local, desse modo, é aquele que se refere, primariamente e diretamente, sem dúvida, ao agrupamento humano local, mas que também atende a interesses do Estado e de todo o país. Claro que cabe ao Município atender a seu peculiar interesse, sendo ilícita a interferência da União e do Estado em assuntos da competência exclusiva da Comuna, o que acarretaria lesão à autonomia loca..$^{83} \mathrm{O}$ Município tem o poder-dever de repelir tais ingerências. Caso ocorra a mencionada invasão em sua autonomia, cabe, inclusive, recurso ao Poder Judiciário para que se anule $o$ ato indébito e inconstitucional da intervenção. Como legislar é uma das formas de administrar, o Município administra, também, quando legisla sobre assuntos de interesse local (art. 30, I da Constituição de 1988). ${ }^{84}$

O interesse local não deve ser entendido como interesse privativo do município, mas sim, interesse prevalentemente local, atendendo às necessidades locais, ainda que tenham alguma repercussão sobre as necessidades

${ }^{82}$ BRASIL. Constituição (1988). Constituição da República Federativa do Brasil. Brasília: Congresso Nacional, 1988. "Art. 30. Compete aos Municípios:I - legislar sobre assuntos de interesse local".

83 "O poder constituinte dos Estados-membros está limitado pelos princípios da Constituição da República, que lhes assegura autonomia com condicionantes, entre as quais se tem o respeito à organização autônoma dos Municípios, também assegurada constitucionalmente. O art. 30, I, da Constituição da República outorga aos Municípios a atribuição de legislar sobre assuntos de interesse local". BRASIL. Supremo Tribunal Federal. Revista Trimestral de Jurisprudência, v. 202, n. 3, outubro a dezembro de 2007, p. 923 a 1866.

${ }^{84}$ CRETELLA JÚNIOR, José. Comentários à Constituição de 1988. Rio de Janeiro: Forense Universitária, 1991. gerais do Estado, ou mesmo da União. ${ }^{85}$ Assim, é correto afirmar que os Municípios estão dotados de todos os poderes inerentes à faculdade de dispor sobre tudo aquilo que diga respeito aos interesses locais. Ainda que perdure certa imprecisão conceitual, porquanto o interesse local se reflete sobre os interesses regionais ou nacionais, é possível identifica-lo a partir das necessidades do município, mesmo irradiando influência sobre as necessidades gerais. ${ }^{86}$

De fato, o uso de bens públicos municipais inserese no conceito de:

[...] matéria de interesse puramente local, inexistindo sobre o assunto qualquer norma geral, ou o que o valha, de matriz constitucional, que seja indistintamente aplicável a todo ente público. A fonte de direito a reger as concessões de uso de bem público é, portanto, sempre local, jamais se podendo invocar norma de outra esfera. Questões, por exemplo, como a licitabilidade, ou a onerosidade dessa espécie de concessão, devem sempre ser resolvidos na legislação local, não se podendo invocar a grosseira generalização que se lê no caput, do art. $2^{\circ}$, da lei nacional de licitações, como cogente para este caso; com efeito, a Lei $n^{\circ} 8.666 / 93$ generaliza o instituto da concessão como se as cinco espécies de concessão existentes no direito brasileiro fossem uma só coisa, igualmente e sempre licitável, porém o faz com a alegre despreocupação dos jejunos em direito, que jamais ouviram falar em divisão constitucional de competências legislativas, nem de constituições estaduais, nem de leis orgânicas municipais, cada qual com suas

${ }^{85}$ Há quem vá mais longe: CARRAZA (1991) pondera que, interesse local seria "tudo aquilo que o próprio município, por meio de lei, vier a entender de seu interesse". E complementa: "interesses dos municípios são os que atendem, de modo imediato, às necessidades locais, ainda que com alguma repercussão sobre as necessidades gerais do Estado ou do País". CARRAZA, Roque Antonio. Curso de direito constitucional tributário. 3. ed. São Paulo: Revista dos Tribunais, 1991.

${ }^{86}$ FERREIRA, Pinto. Curso de direito constitucional. 9. ed. São Paulo: Saraiva, 1998. 
competências rigidamente predeterminadas na carta magna. ${ }^{8788}$

A autonomia municipal para a gestão do seu patrimônio foi ratificada em diversos dispositivos legais. E não poderia ser diferente. Deveras, constitui dever constitucionalmente imposto ao Município, por força do disposto no artigo 30, VIII, combinado com o artigo 182, $\$ 1^{\circ}$, da Carta Federal, ordenar o pleno desenvolvimento das funções sociais da cidade e garantir o bem-estar de seus habitantes. Essa missão foi corroborada com a edição do Estatuto da Cidade ${ }^{89}$ (Lei no 10.257/2001), de cujo teor se extraem diversas atribuições outorgadas aos entes municipais, dentre as quais a competência legislativa municipal para determinação da utilização de solo urbano ${ }^{90}$ para

${ }^{87}$ RIGOLIN, Ivan Barbosa. Concessão, permissão, autorização, cessão e doação. Quais são as diferenças? In: FÓRUM DE CONTRATAÇÃO E GESTÃO PÚBLICA, 2004, Belo Horizonte. Belo Horizonte: Fórum, 2004.

${ }^{88}$ Impende consignar que a matéria é controversa. Com efeito, ao analisar a questão pertinente à organização territorial, o Supremo Tribunal Federal entendeu pela submissão da matéria ao direito urbanístico, de que trata o art. 24, I, da Constituição Federal, estando, desta forma, submetida à competência da União e dos Estados quanto à edição de normas gerais: "A criação, a organização e a supressão de distritos, da competência dos Municípios, faz-se com observância da legislação estadual (CF, art. 30, IV). Também a competência municipal, para promover, no que couber, adequado ordenamento territorial, mediante planejamento e controle do uso, do parcelamento e da ocupação do solo urbano - CF, art. 30, VIII - por relacionar-se com o direito urbanístico, está sujeita a normas federais e estaduais (CF, art. 24, I). As normas das entidades políticas diversas - União e Estado-membro - deverão, entretanto, ser gerais, em forma de diretrizes, sob pena de tornarem inócua a competência municipal, que constitui exercício de sua autonomia constitucional." BRASIL. ADI 478, Rel. Min. Carlos Velloso, Plenário, Diário da Justiça, Brasília, 28 fev. 1997. Disponível em: <http://redir.stf.jus.br/ paginadorpub/paginador.jsp?doc $\mathrm{TP}=\mathrm{AC} \& \operatorname{doc} \mathrm{ID}=266374>$. Acesso em: 20 mar. 2012.

${ }^{89}$ BRASIL. Lei n. 10.257, de 10 de julho de 2001. Disponível em: < http://www.planalto.gov.br/ccivil_03/leis/leis_2001/110257. htm>. Acesso em: 20 mar. 2012. Art. 1º. Parágrafo único. Para todos os efeitos, esta Lei, denominada Estatuto da Cidade, estabelece normas de ordem pública e interesse social que regulam o uso da propriedade urbana em prol do bem coletivo, da segurança e do bem-estar dos cidadãos, bem como do equilíbrio ambiental.

${ }^{90}$ BRASIL. Lei n. 10.257, de 10 de julho de 2001. Disponível em:

< http://www.planalto.gov.br/ccivil_03/leis/leis_2001/110257. htm>. Acesso em: 20 mar. 2012. Art. 5. Lei municipal específica para área incluída no plano diretor poderá determinar o parcelamento, a edificação ou a utilização compulsórios do solo urbano não edificado, subutilizado ou não utilizado, devendo fixar as condições e os prazos para implementação da referida obrigação. proceder à desapropriação e consequente aproveitamento de imóvel urbano ${ }^{91}$ e formular política de desenvolvimento urbano, com a definição dos parâmetros de uso do solo urbano. ${ }^{92}$

É sob essa perspectiva que surge evidente a autonomia que o Texto Constitucional pretendeu emprestar ao município, e autonomia esta que deve ser entendida como a capacidade de autodeterminação dentro de um rol de competências garantidoras de sua auto-organização, autogoverno, autolegislação e autoadministração. ${ }^{93}$ Isso porque, como é cediço, o Estado Federal é uma forma de Estado composto, onde identifica-se a união de comunidades públicas dotadas, cada uma, de autonomia constitucional e política, cujos lindes são ditados pelos princípios inseridos no Texto Constitucional, fonte da organização dos Entes Federados.

Ao prever o regime Federativo, a Constituição consagra a descentralização do poder político, possibilitando sua repartição entre os entes coletivos que o

${ }_{91}$ BRASIL. Lei n. 10.257, de 10 de julho de 2001. Disponível em: < http://www.planalto.gov.br/ccivil_03/leis/leis_2001/110257. htm>. Acesso em: 20 mar. 2012. Art. 8. Decorridos cinco anos de cobrança do IPTU progressivo sem que o proprietário tenha cumprido a obrigação de parcelamento, edificação ou utilização, o Município poderá proceder à desapropriação do imóvel, com pagamento em títulos da dívida pública..

$\$ 4^{\circ}$. O Município procederá ao adequado aproveitamento do imóvel no prazo máximo de cinco anos, contado a partir da sua incorporação ao patrimônio público.

92 BRASIL. Lei n. 10.257, de 10 de julho de 2001. Disponível em:

< http://www.planalto.gov.br/ccivil_03/leis/leis_2001/110257. htm>. Acesso em: 20 mar. 2012. Art. 40. O plano diretor, aprovado por lei municipal, é o instrumento básico da política de desenvolvimento e expansão urbana. Art. 42-A. Os municípios que possuam áreas de expansão urbana deverão elaborar Plano de Expansão Urbana no qual constarão, no mínimo:

IV - definição de parâmetros de parcelamento, uso e ocupação do solo, de modo a promover a diversidade de usos e contribuir para a geração de emprego e renda; (Incluído pela Medida Provisória no 547, de 2011).

93 "A autonomia municipal, assim, assenta em quatro capacidades: a) Capacidade de auto-organização, mediante a elaboração da lei orgânica própria; b) Capacidade de auto-governo, eletividade do Prefeito e dos Vereadores às respectivas Câmaras Municipais; c) Capacidade normativa própria, ou capacidade de autolegislação, mediante a competência de elaboração de leis municipais sobre áreas que são reservadas à sua competência exclusiva ou suplementar; d) Capacidade de auto-administração (administração própria, para manter e restar os serviços de interesse local)". SILVA, José Afonso. Curso de direito constitucional positivo. 34. ed. São Paulo: Malheiros, 2011. p. 621. 
compõem, os quais participam da formação da vontade da União. Assim o fez a Constituição brasileira, ao determinar a existência de várias ordens, dotadas de autonomia político-administrativa: a União, como a ordem nacional; os Estados, como ordens regionais; e os Municípios, como ordens locais, cada uma delas com um feixe de competências constitucionalmente definidas. Essa configuração política permite que sobre um mesmo povo, sobre um mesmo território, incidam diversas ordens político-legislativas, fenômeno decorrente da repartição de competências entre os entes federativos. ${ }^{94}$

O critério geral que norteou o legislador constitucional foi a predominância de interesses. Assim, para a União, a Constituição reserva competência legislativa atinente a assuntos de interesse nacional. Aos Estados, restou delegada atribuição pertinente a assuntos de interesse regional, enquanto aos Municípios incumbe o regramento acerca de matérias atinentes ao interesse local. ${ }^{95}$ Dessa forma, é o interesse local que irá definir a competência municipal na seara legislativa. Sempre que ele for identificado, ainda que reflexamente o interesse em questão tenha impacto regional, ou mesmo nacional - o que se verifica amiúde, ${ }^{96}$ ainda assim, será hipótese de conferir ao Município o seu regramento.

A outorga aos entes municipais das competências previstas no Estatuto da Cidade corrobora a autonomia municipal, pilar sobre o qual se assenta a estrutura federativa brasileira. A subtração da autonomia municipal em tais casos, quando interesses locais relativos à ocupação urbana estão em jogo, implicaria ofensa à repartição de competências constitucionalmente consagradas.

94 “[...] em uma federação não existe hierarquia das leis decorrente do ente federado que as editou, pois não há hierarquia entre os entes federativos". PRESTES, Vanêsca Buzelato. A concessão especial para fins de moradia na Constituição Federal e no Estatuto da Cidade - da constitucionalidade da Medida Provisória no 2.220 de 04 de setembro de 2001. FERNANDES, Edésio; ALFONSIN, Betânia de Moraes (Org.). Direito à moradia e segurança da posse no statuto da cidade: diretrizes, instrumentos e processos de gestão. Porto Alegre: Fórum, 2004. p. 203.

95 TEIXEIRA, José Horácio Meirelles. Curso de direito constitucional. Rio de Janeiro: Forense Universitária, 1990.

96 "O interesse local se caracteriza pela predominância e não pela exclusividade do interesse para o Município, em relação ao do Estado e da União. Isso porque não há assunto municipal que não seja reflexamente de interesse estadual e nacional. A diferença é apenas de grau, e não de substância”. MEIRELLES, Hely Lopes. Direito administrativo brasileiro. 33. ed. São Paulo: Malheiros, 2007. p. 120.
Iniciativas de planejamento urbano, aliadas a estratégias de desenvolvimento local, como a utilização de instrumentos urbanísticos que promovam e garantam a melhor utilização patrimonial, inserem-se no plexo de atribuições do município, que deve gozar de autonomia na definição dos seus respectivos procedimentos. Aliás, a grande inovação trazida pelo capítulo de política urbana da Constituição de 1988 foi inserir a definição do conteúdo jurídico da propriedade urbana no processo político de elaboração, aprovação e implementação dos Planos Diretores Municipais. ${ }^{97}$

A exigência da gestão democrática prevista no Estatuto da Cidade, que exige a participação popular no processo de elaboração do Plano Diretor, e, assim, na definição dos rumos da cidade, culmina na responsabilização do gestor municipal por improbidade administrativa em caso de descumprimento de tal mandamento. Nessa perspectiva, compete à lei local estabelecer a disciplina legal aplicável ao instituto da concessão de uso de bens públicos pertencentes ao Município, fixando por completo as condições e as regras a serem observadas na celebração dos respectivos contratos. Daí decorre que "[...] pode haver concessão de uso sem prévia licitação - é dizer que para a outorga do uso privativo não é inafastável a regra de licitar, como é no caso da concessão de serviço público", sendo tal entendimento "reforçado pelo disposto no art. 176, parágrafo $4^{\circ}$, da Constituição, que prevê a “[...] prescindibilidade de licitação para concessão da exploração de potencial de aproveitamento (bem público) de energia de capacidade reduzida". 98

Não obstante estar infensa à observância obrigatória das regras de contratação pública exprimidas no

97 “O Plano Diretor é incumbido da tarefa de estabelecer normas imperativas aos agentes públicos e privados, metas e diretrizes da política urbana, os critérios para verificar se a propriedade atende sua função social, as normas condicionadoras do exercício desse direito, a fim de alcançar os objetivos desta política: garantir as condições dignas de vida urbana, o pleno desenvolvimento das funções sociais da cidade e o cumprimento da função social da propriedade pública e privada”. CARDOSO, Patrícia de Menezes. Democratização do acesso à propriedade pública no Brasil: função social e regularização fundiária. Pontifícia Universidade Católica de São Paulo, 2010. Disponível em: < http://patrimoniodetodos.gov. br/olhares-sobre-o-patrimonio-de-todos >. Acesso em: 20 mar. 2012.

${ }^{98}$ MARQUES NETO, Floriano de Azevedo. Bens públicos: função social e exploração econômica: o regime jurídico das utilidades públicas. Belo Horizonte: Fórum, 2009. 
bojo da Lei $\mathrm{n}^{\circ} 8.666 / 93$, nada impede que o legislador local, no uso de sua competência constitucionalmente delimitada, preveja sua utilização quando da outorga de uso dos bens públicos. Isso porque, consoante restou demonstrado, às concessões de uso não é imposta a observância obrigatória das disposições normativas constantes da Lei no 8.666/93, dada a incompetência da União para legislar sobre tal matéria. Essa circunstância, no entanto, não afasta, tout court, a possibilidade de haver licitação prévia às outorgas de uso de bens públicos, mediante a imposição do referido procedimento pelo ente federativo competente. Aliás, pode-se ponderar que, diferentemente do que ocorre na concessão de serviço público, para a qual há obrigação de licitar previamente à outorga, advinda da disposição constitucional incontornável do art. 175, no caso da concessão de uso de bem público a observância ao prévio processo licitatório pode ser extraída da regra geral do art. 37, ${ }^{99}$ sob uma perspectiva principiológica.

Com efeito, por representar um meio de concretização dos princípios da moralidade e da impessoalidade, princípios estes consagrados constitucionalmente e que devem nortear toda a atividade administrativa, a submissão da outorga de uso de bem público ao procedimento licitatório, ainda quando dispensável, é sempre uma salutar forma de escolha da destinação dos recursos públicos. ${ }^{100}$ Assim, sob a perspectiva de que o processo licitatório orienta-se por dois objetivos, quais sejam, selecionar a proposta mais vantajosa às entidades governamentais e permitir a qualquer interessado em celebrar contratos com a Administração a participação no certame, garantindo aos administrados o respeito à isonomia, sobressai a relevância em considerar sua adoção sempre que houver ato de disposição do patrimônio público. Ainda que se considere facultativa, a sua adoção resguarda o administrado de futuros questionamentos, em sede de Ação de Improbidade Administrativa, acerca da motivação do ato praticado, uma vez que todo o procedimento administrativo há que encontrar esteio em um interesse público subjacente.

\footnotetext{
${ }^{99}$ BRASIL. Constituição (1988). Constituição da República Federativa do Brasil Brasília: Congresso Nacional, 1988. "Art. 37. A administração pública direta e indireta de qualquer dos Poderes da União, dos Estados, do Distrito Federal e dos Municípios obedecerá aos princípios de legalidade, impessoalidade, moralidade, publicidade e eficiência e, também, ao seguinte: $[\ldots]$ ".

${ }^{100}$ BRASIL: Tribunal de Contas da União. Acórdão 1054/2004 Plenário. Disponível em: < http://contas.tcu.gov.br/portaltextual/ServletTcuProxy >. Acesso em: 20 mar. 2012.
}

Deveras, a outorga de uso de bens públicos não precedida de licitação tem ensejado a proposição de diversas ações judiciais, nas quais se questiona a conduta do gestor municipal relativamente ao respeito aos princípios que devem nortear a atividade administrativa. ${ }^{101}$ Dessa forma, pode-se ponderar que a adoção da licitação em todos os procedimentos de outorga do uso de bens públicos parece mais consentânea com a Constituição Federal e os princípios que dela se extraem, sendo recomendável aos entes municipais e estaduais sua inserção nas respectivas legislações.

Mesmo nas hipóteses de "ofertas não solicitadas", caso em que é o particular que aciona o poder público no afã de usufruir de determinado bem público, a adoção da licitação se mostra pertinente. Nesses casos, o procedimento concorrencial imprime ao ato administrativo a nota da isonomia, bem como a publicidade e a transparência, princípios cuja aplicabilidade é reclamada pelo Texto Constitucional.

\section{Considerações finais}

O Estado exerce um papel decisivo na efetivação dos direitos fundamentais dos seus cidadãos. A fim de proporcionar um ambiente favorável ao desenvolvimento social saudável, é necessário priorizar a alocação de serviços e produtos em favor da parcela da população historicamente desfavorecida.

Em um contexto de escassez de recursos e crescente demanda social, faz-se premente empreender esforços para dinamizar a propriedade estatal, direcionandoa para a consecução de fins de interesse público, o que representa um autêntico poder-dever do gestor público, não somente quanto ao aspecto de rentabilização dos bens públicos, por si só relevante, mas igualmente no

${ }^{101}$ SÃO PAULO. Tribunal de Justiça. CR 7804665300. 6a Câmara de Direito Público. Publicado em 26 de agosto de 2008. Disponível em: < http://www.jusbrasil.com.br/jurisprudencia/3402695/apelacao-com-revisao-cr-7804665300-sp-tjsp >. Acesso em: 20 mar. 2012. "Ato de improbidade administrativa. Permissão/concessão de uso de bem público sem licitação. IMPOSSIBILIDADE. O Contrato Administrativo exige licitação prévia, só dispensável ou inexigível nos casos expressamente previstos em lei (art. 37, XXI e 175, da CF; art. 20 da Lei 8.666/93). A improbidade independe de dolo, ou prejuízo ao erário (art.37,caput, da Constituição Federal e art. 11, da Lei 8.429/92)". 
prestígio à função social da propriedade ${ }^{102}$ vetor constitucional de aplicabilidade ampla, tanto a bens particulares, quanto públicos. ${ }^{103}$

A prossecução das finalidades públicas ora em voga, pertinentes à implementação de "políticas de inclusão social, preservação ambiental e apoio à provisão habitacional para a população de baixa renda", como pretende o atual Governo Brasileiro, demanda a eleição de critérios coerentes de escolha da destinação do patrimônio coletivo. A superação da tradicional atuação cartorial da Administração Pública, moldando-a com lastro na discussão qualitativa e propositiva sobre o uso a ser conferido ao patrimônio público, é condição para que a propriedade pública atenda aos fins de interesse público, cumpra a função social ao qual é constitucionalmente compelida e concorra para desenvolvimento sustentável da nação.

No contexto brasileiro atual, o binômio proteção-rentabilização assume a característica triangular: acresce-se à preocupação do legislador e do intérprete a necessidade de se imprimir ao regime jurídico da propriedade pública (coletiva) o viés social, característica de várias políticas públicas engendradas no panorama brasileiro e objeto de relevantes alterações legislativas recentes.

A forma como se encara o patrimônio público vem sofrendo significativa evolução: nota-se hoje nítida mudança de paradigma, deslocando-se o eixo, antes centrado no valor de troca (potencial econômico decorrente de relação comutativa) para o valor de uso (potencial econômico decorrente de relação utilitária). A partir daí, a sujeição de um determinado bem a um regime jurídico deve ter como baliza o uso ao qual ele está vocacionado.

A funcionalização da propriedade impacta significativamente o seu regime jurídico, que passa a orientar-se não pela sua natureza dominial, mas pela relevância dos usos a que se presta e das utilidades que dela se possam

${ }^{102}$ BRASIL. Constituição (1988). Constituição da República Federativa do Brasil. Brasília: Congresso Nacional, 1988. "Art. $5^{\circ}$ Todos são iguais perante a lei, sem distinção de qualquer natureza, garantindo-se aos brasileiros e aos estrangeiros residentes no País a inviolabilidade do direito à vida, à liberdade, à igualdade, à segurança e à propriedade, nos termos seguintes: [...]XXIII - a propriedade atenderá a sua função social".

${ }^{103}$ DI PIETRO, Maria Sylvia Zanella. Função social da propriedade pública. Revista Eletrônica de Direito do Estado, Salvador, n. 6, p. 1-13, trimestral, 2006. extrair. Nessa perspectiva, a gestão dos bens públicos há que ser orientada sempre de molde a permitir o máximo aproveitamento da propriedade, não só sob o aspecto de geração de receitas, mas, primacialmente, com o fim de instrumentalizar a concretização de políticas públicas.

Assim, sobressai fundamental a consolidação de um conceito de propriedade pública que atenda às necessidades contemporâneas da sociedade, mediante a implementação de uma gestão democrática dos imóveis públicos que traduza eficiência econômica, racionalidade administrativa, justiça socioambiental e segurança jurídica. A construção da cidade democrática pressupõe um ambiente onde a utilização do patrimônio público seja orientada de molde a concretizar os direitos fundamentais da pessoa humana.

Nesse cenário, revela-se a importância da delimitação e correta exegese do regime jurídico aplicável aos instrumentos utilizados na dinamização do patrimônio público. Em que pese respeitável opinião doutrinária e jurisprudencial divergente, a análise criteriosa do feixe de competências legislativas estabelecido constitucionalmente, em cotejo com os diplomas infraconstitucionais em vigor, em especial a Lei $n^{\circ} 8.666 / 93$ revela a impertinência de sua invocação para o tratamento jurídico adequado às outorgas de uso de bens públicos, ainda quando revestidas da forma contratual.

Com efeito, a outorga constitucional de competência que prefixa tarefas próprias para a União não quebra os poderes e a autonomia em relação às tarefas que $o$ Texto Constitucional delegou aos Estados e aos Municípios, apenas resguarda a Integridade Nacional. Sob essa perspectiva, parece igualmente correto afirmar que a previsão do feixe de competências reservadas aos Estados e Municípios prestigia o princípio federativo, conferindolhes a autonomia em que se assenta a organização do Estado Brasileiro.

A análise sistemática do arcabouço jurídico pertinente revela que a outorga do uso de bens públicos insere-se no conceito de "assunto de interesse local", submetido, por expresso comando constitucional, à competência legislativa local, circunstância que afasta, nesse particular, a aplicação cogente da Lei no 8.666/93. Conquanto, não submetida às regras de contratação pública contidas na Lei de Licitações, a outorga de uso de bens públicos deve sempre ser efetivada no afã de concretizar 
os princípios constitucionais que pautam a atividade administrativa, estes de observância obrigatória em todas as ações engendradas pelo Poder Público. Nesse contexto, o procedimento de licitação, ainda quando dispensável pela Lei $n^{\circ} 8.666 / 93$, pode constituir instrumento apto à concretização dos princípios constitucionais, viabilizando a melhor escolha pela Administração Pública, quando está em causa a destinação dos bens públicos.

\section{Referências}

ABE, Nilma de Castro. Notas sobre a inaplicabilidade da função social à propriedade pública. Revista Brasileira de Direito Constitucional, n. 11, p. 135-154, jan./jun. 2008.

ARAÚJO, Edmir Netto. Curso de direito administrativo. São Paulo: Saraiva, 2005.

BRASIL. Constituição (1988). Constituição da República Federativa do Brasil. Brasília: Congresso Nacional, 1988.

BRASIL. Constituição (1824). Constituição Política do Império do Brasil. Rio de Janeiro: Imprensa Nacional, 1824.

BRASIL. Decreto-Lei n. 271, de 28 de fevereiro de 1967. Disponível em < http://www.planalto.gov.br/ccivil_03/ decreto-lei/del0271.htm >. Acesso em: 20 mar. 2012.

BRASIL. Lei n. 8.666, de 21 de junho de 1993. Disponível em: < http://www.planalto.gov.br/ccivil_03/leis/ 18666cons.htm>. Acesso em: 20 mar.

BRASIL. Lei n. 8.987, de 13 de fevereiro de 1995. Disponível em: <http://www.planalto.gov.br/ccivil_03/ leis/18987cons.htm $>$. Acesso em: 20 mar.

BRASIL. Lei n. 10.257, de 10 de julho de 2001. Estatuto da cidade. Disponível em: < http://www.planalto.gov. br/ccivil_03/leis/leis_2001/110257.htm>. Acesso em: 20 mar. 2012.

BRASIL. Lei n. 10.406, de 10 de janeiro de 2002. Código civil brasileiro. Disponível em: < http://www.planalto.gov. br/ccivil_03/leis/2002/110406.htm >. Acesso em: 20 mar. 2012.

BRASIL. Lei n. 11.481, de 31 de maio de 2007. Disponível em: < http://www.planalto.gov.br/ccivil_03/_ato20072010/2007/Lei/L11481.htm>. Acesso em: 20 mar. 2012.

BRASIL. Lei n. 12.349, de 15 de dezembro de 2010. Disponível em: <http://www.planalto.gov.br/ccivil_03/_ Ato2007-2010/2010/Lei/L12349.htm>. Acesso em: 20 mar. 2012.
BRASIL. Ministério das Cidades. Política Nacional de Habitação. 2004. Disponível em <http://www.cidades. gov.br>. Acesso em: 20 mar. 2012.

BRASIL. Ministério do Planejamento. Secretaria de Patrimônio da União. Disponível em: <http:// patrimoniodetodos.gov.br/politica-nacional-de-gestaodo-patrimonio-da-uniao-pngpu $>$. Acesso em: 20 mar. 2012.

BRASIL. Presidência da República. Câmara da Reforma do Estado. Plano diretor da reforma do aparelho do estado. Brasília: Imprensa Nacional, 1995.

BRASIL. Superior Tribunal de Justiça. RMS 16280/RJ. Diário de Justiça, Rio de Janeiro, 19 abr. 2004.

BRASIL. Supremo Tribunal Federal. ADI 478, Plenário. Diário de Justiça, Brasília, 28 fev. 1997. Disponível em: < http://redir.stf.jus.br/paginadorpub/ paginador.jsp? docTP=AC\&docID $=266374>$. Acesso em: 20 mar. 2012.

BRASIL. Supremo Tribunal Federal. Revista Trimestral de Jurisprudência, v. 202, n. 3, outubro a dezembro de 2007, p. $923-1866$.

BRASIL. Tribunal de Contas da União. Revista do TCU, v. 38, n. 108, jan/abr de 2007. Disponível em: < http:// portal2.tcu.gov.br/portal/pls/portal/docs/2054060.PDF >. Acesso em: 20 mar. 2012.

BRASIL. Tribunal de Contas da União. Acórdão 1054/2004 - Plenário. Disponível em: < http://contas.tcu. gov.br/portaltextual/ServletTcuProxy >. Acesso em: 20 mar. 2012.

CAETANO, Marcello. Manual de direito administrativo. Rio de Janeiro: Forense, 1970.

CARDOSO, Patrícia de Menezes. Democratização do acesso à propriedade pública no Brasil: Função social e regularização fundiária. Pontifícia Universidade Católica de São Paulo, 2010. Disponível em < http:// patrimoniodetodos.gov.br/olhares-sobre-o-patrimoniode-todos > . Acesso em: 20 mar. 2012.

CARVALHO FILHO, José dos Santos. A autorização de uso de bem público de natureza urbanística. Disponível em: <http://www.mundojuridico.adv.br >. Acesso em: 20 mar. 2012.

CARVALHO FILHO, José dos Santos. Manual de direito administrativo. 15. ed. Rio de Janeiro: Lumen Juris, 2006. 
CARRAZA, Roque Antonio. Curso de direito constitucional tributário. 3. ed. São Paulo: Revista dos Tribunais, 1991.

CRETELLA JÚNIOR, José. Comentários à Constituição de 1988. Rio de Janeiro: Forense Universitária, 1991. v. 4.

CRETELLA JÚNIOR, José. Dos bens públicos na Constituição de 1988. Revista dos Tribunais, São Paulo, v. 79, n. 653, p. 16-48, mar. 1990.

CRETELLA JÚNIOR, José. Tratado do domínio público. Rio de Janeiro: Forense, 1984.

DI PIETRO, Maria Sylvia Zanella. 500 anos de direito administrativo brasileiro. R. Brasileira de Direito Público, Belo Horizonte, v. 1, p. 181-210, abr./jun. 2003.

DI PIETRO, Maria Sylvia Zanella. Direito administrativo. 24. ed. São Paulo: Atlas, 2011.

DI PIETRO, Maria Sylvia Zanella. Função social da propriedade pública. R. Eletrônica de Direito do Estado, Salvador, n. 6, trimestral, p. 1-13, 2006.

DIPIETRO, Maria Sylvia Zanella. Servidão administrativa. São Paulo: Revista dos Tribunais, 1978.

DI PIETRO, Maria Sylvia Zanella. Uso privativo de bem público por particular. São Paulo: Revista dos Tribunais, 1983.

FAORO, Raymundo. Os donos do poder: formação do patronato político brasileiro. 3. ed. São Paulo: Globo, 2001.

FERNANDES, Edésio; ALFONSIN, Betânia de Moraes (Org.). Direito à moradia e segurança da posse no statuto da cidade: diretrizes, instrumentos e processos de gestão. Porto Alegre: Fórum, 2004.

FERREIRA, Pinto. Curso de direito constitucional. 9 ed. São Paulo: Saraiva, 1998.

IGLESIAS, Sérgio Nunes de Souza. Direito à moradia e de habitação: análise comparativa de suas implicações teóricas e práticas com os direitos da personalidade. São Paulo: Revista dos Tribunais, 2004.

MARQUES NETO, Floriano de Azevedo. Bens públicos: função social e exploração econômica. O Regime Jurídico das Utilidades Públicas. Belo Horizonte: Fórum, 2009.

MEDAUAR, Odete. Direito administrativo em evolução. São Paulo: Revista dos Tribunais, 2003.
MEIRELLES, Hely Lopes. Direito administrativo brasileiro. 33 ed. São Paulo: Malheiros, 2007.

MELLO, Celso Antônio Bandeira. Curso de direito administrativo. 25. ed. São Paulo: Malheiros, 2008.

MELLO, Celso Antônio Bandeira. Desapropriação de bem público. Revista de Direito Público, São Paulo, ano 7 , n. 29, p. 47-60, trimestral, 1974.

MELLO, Celso Antônio Bandeira. Serviço público: conceito e características. Biblioteca Jurídica Virtual Del Instituto de Investigaciones Jurídicas de la UNAM. Disponível em: <www.juridicas.unam.mx>. Acesso em: 20 mar. 2012.

MONIZ, Ana Raquel Gonçalves Moniz. Contrato público e domínio público. Os contratos sobre o domínio público à luz do Código dos Contratos Públicos e da Nova Legislação sobre o domínio público. In: GONÇALVES, P. (Org.). Estudos de contratação pública - I. Coimbra: Coimbra, 2008.

MOREIRA NETO, Diogo de Figueiredo. Curso de direito administrativo. 15. ed. Rio de Janeiro: Forense, 2009.

OTÁVIO, Rodrigo. Do domínio da União e dos Estados segundo a Constituição Federal. 2. ed. São Paulo: Saraiva, 1924.

PRESTES, Vanêsca Buzelato. A concessão especial para fins de moradia na Constituição Federal e no Estatuto da Cidade: da constitucionalidade da Medida Provisória $\mathrm{n}^{\circ} 2.220$ de 04 de setembro de 2001. In: ALFONSIN, B.; FERNANDES, E. Direito à moradia e segurança da posse no Estatuto da Cidade. Belo Horizonte: Fórum, 2004.

RIGOLIN, Ivan Barbosa. Concessão, permissão, autorização, cessão e doação: quais as diferenças? In. FÓRUM DE CONTRATAÇÃO E GESTÃO PÚBLICA, 2004, Belo Horizonte. Belo Horizonte: Fórum, 2004.

SANTOS, Boaventura de Souza. A gramática do tempo: para uma nova cultura política. São Paulo: Cortez, 2006.

SÃO PAULO. Tribunal de Justiça. CR 7804665300. 6 6 $^{\mathrm{a}}$ Câmara de Direito Público. Publicado em 26 de agosto de 2008. Disponível em: < http://www.jusbrasil.com. br/jurisprudencia/3402695/apelacao-com-revisao-cr7804665300-sp-tjsp >. Acesso em: 20 mar. 2012.

SILVA, José Afonso. Comentário contextualà Constituição. 7. ed. São Paulo: Malheiros, 2010.

SILVA, José Afonso. Curso de direito constitucional positivo. 34. ed. São Paulo: Malheiros, 2011. 
SUNDFELD, Carlos Ari; CÂMARA, Jacintho de Arruda. Concessão de direito real de uso de utilidade pública: possibilidade de o poder público conferir a particular a gestão exclusiva de seu bens para fins de utilidade pública. Hipótese em que a outorga independerá de licitação, por ser esta inexigível. Boletim de licitações e contratos, São Paulo, v. 10, n. 12, p. 593-602, mensal, 1997.
TEIXEIRA, José Horácio Meirelles. Curso de direito constitucional. Rio de Janeiro: Forense Universitária, 1990. 


\section{Para publicar na revista Universitas/JUS, acesse $o$ endereço eletrônico www.publicacoesacademicas.uniceub.br.}

Observe as normas de publicação, para facilitar e agilizar o trabalho de edição. 